\title{
Global approaches to addressing biofuel- related invasive species risks and incorporation into U.S. laws and policies
}

Authors (in alphabetical order): Kristin C. Lewis (Volpe National Transportation Systems Center) and Read Porter (Environmental Law Institute)

Final Report - May 2014

DOT-VNTSC-FAA-12-02

DOT/FAA/AEE/2011-08

Prepared for:

Federal Aviation Administration

Office of Environment and Energy

Washington, DC 


\section{Notice}

This document is disseminated under the sponsorship of the Department of Transportation in the interest of information exchange. The United States Government assumes no liability for the contents or use thereof.

The United States Government does not endorse products or manufacturers. Trade or manufacturers' names appear herein solely because they are considered essential to the objective of this report. 


\section{REPORT DOCUMENTATION PAGE}

\section{Form Approved \\ OMB No. 0704-0188}

Public reporting burden for this collection of information is estimated to average 1 hour per response, including the time for reviewing instructions, searching existing data sources, gathering and maintaining the data needed, and completing and reviewing the collection of information. Send comments regarding this burden estimate or any other aspect of this collection of information, including suggestions for reducing this burden, to Washington Headquarters Services, Directorate for Information Operations and Reports, 1215 Jefferson Davis Highway, Suite 1204, Arlington, VA 22202-4302, and to the Office of Management and Budget, Paperwork Reduction Project (0704-0188), Washington, DC 20503.

\begin{tabular}{|l|l|c|c|}
\hline 1. AGENCY USE ONLY (Leave blank) & $\begin{array}{l}\text { 2. REPORT DATE } \\
\text { May } 2014\end{array}$ & $\begin{array}{c}\text { 3. REPORT TYPE AND DATES COVERED } \\
\text { Final Report }\end{array}$ \\
\hline
\end{tabular}

\section{TITLE AND SUBTITLE}

Biofuels and invasive species risks: assessing and managing risks through feedstock selection and cultivation strategies

6. AUTHOR(S)

Kristin Lewis ${ }^{(1),}$ Read Porter ${ }^{(2)}$ (note authors share priority and are listed alphabetically)

7. PERFORMING ORGANIZATION NAME(S) AND ADDRESS(ES)

U.S. Department of Transportation

John A Volpe National Transportation Systems Center

55 Broadway

Cambridge, MA 02142-1093

9. SPONSORING/MONITORING AGENCY NAME(S) AND ADDRESS(ES)

US Department of Transportation

5a. FUNDING NUMBERS

RR04A2 HG384

Federal Aviation Administration,

Office of Energy and Environment

800 Independence Ave., SW, Washington, DC 20591

11. SUPPLEMENTARY NOTES

1) U.S. Department of Transportation, Volpe, The National Transportation Systems Center, Energy Analysis and Sustainability Division, Cambridge, MA 02142

(2) Environmental Law Institute 2000 L St. NW, Suite 620, Washington, DC 220036

12a. DISTRIBUTION/AVAILABILITY STATEMENT

This document is available to the public on the National Transportation Library website.

13. ABSTRACT (Maximum 200 words)

Biofuels are being pursued for their potential greenhouse gas emissions benefits, among other reasons. In order to maximize productivity, avoid food-fuel conflicts, and minimize GHG emissions, many "advanced" biofuel feedstock crops, such as those desired by the aviation community, are under consideration based on traits, such as high biomass and/or seed production, tolerance of marginal cultivation conditions, and short generation times, that may also be predictors of potential invasiveness risk. Biofuel-related invasion risks can be mitigated through careful feedstock crop selection and cultivation techniques developed from the invasion science literature. Existing voluntary best practices and some state and federal regulatory requirements in the United States recommend and/or require the use of such risk mitigation strategies. However, other policies and programs allow or provide incentives for biofuel production without conditions requiring the use of these strategies. This study synthesizes information on the scientific knowledge of invasive species predictors and their use (or absence) in voluntary codes and United States regulatory frameworks and incentive programs. The study highlights the existing tools and approaches for assessing invasion risk and avoiding the introduction and spread of invasive species as a result of biofuel feedstock cultivation. A well-coordinated combination of species restrictions, biosecurity requirements, and incentives for selection of less risky biofuel crops may effectively balance the desire for increased biofuel production while minimizing invasion risk.

\begin{tabular}{|c|c|c|c|}
\hline & $\begin{array}{l}\text { 15. NUMBER OF PAGES } \\
211\end{array}$ \\
\hline \multicolumn{3}{|c|}{$\begin{array}{l}\text { 14. SUBJECT TERMS } \\
\text { alien species, biomass, bioenergy, feedstock, invasion, non-native species, pest risk assessment, weed risk assessment }\end{array}$} & 16. PRICE CODE \\
\hline $\begin{array}{l}\text { 17. SECURITY CLASSIFICATION } \\
\text { OF REPORT } \\
\text { Unclassified }\end{array}$ & $\begin{array}{l}\text { 18. SECURITY CLASSIFICATION } \\
\text { OF THIS PAGE } \\
\text { Unclassified }\end{array}$ & $\begin{array}{l}\text { 19. SECURITY CLASSIFICATION } \\
\text { OF ABSTRACT } \\
\text { Unclassified }\end{array}$ & $\begin{array}{l}\text { 20. LIMITATION OF ABSTRACT } \\
\text { Unlimited }\end{array}$ \\
\hline NSN 7540-01-280-5500 & & & $\begin{array}{l}\text { Standard Form } 298 \text { (Rev. } 2 \\
\text { Prescribed by ANSI Std. 23 }\end{array}$ \\
\hline
\end{tabular}




\section{Acknowledgments}

The authors would like to thank Jim Hileman and Lourdes Maurice (FAA), Matthew Pearlson (Massachusetts Institute of Technology), Todd Atkinson (USDA Farm and Foreign Agricultural Services), Adam Davis (USDA Agricultural Research Service),Andrea Huberty (USDA Biotechnology Regulatory Services), Ron Lundine (USDA Risk Management Agency), Anthony Koop (USDA Plant Protection and Quarantine), Paul Argyropoulos, Vincent Camobreco, Aaron Levy, Caroline Ridley, and Mike Slimak (EPA Office of Transportation and Air Quality), Nancy Young (Airlines for America), and two reviewers for their valuable comments on previous versions of this paper. Additional thanks to student interns/coops Alexander Epstein and Shuchi Mitra (Volpe Center) and Sharee Williamson and Emily Spiegel (ELI) for their assistance. This work is funded by the U.S. Federal Aviation Administration (FAA) Office of Environment and Energy (AEE), under the FAA/Volpe General Working Agreement. This study effort was co-managed by Warren Gillette and Kristin Lewis. Warren Gillette also provided input on the document scope and content and comments on manuscript drafts. This report was prepared by a U.S. government employee in connection with their official duties and therefore is in the public domain pursuant to 17 U.S.C. Section 105. 


\section{TABLE OF CONTENTS}

INTRODUCTION

USE OF INVASIVENESS PREDICTORS IN PRE-INTRODUCTION WEED RISK ASSESSMENT ............23

USE OF WRA TOOLS TO PREDICT INVASION BY BIOFUEL FEEDSTOCK SPECIES...............................31

POST-INTRODUCTION SPECIES ESCAPE AND SPREAD ..........................................................................32

MANAGING INVASION RISKS THROUGH VOLUNTARY BEST PRACTICES .........................................34

REGULATIONS, POLICIES AND INCENTIVES RELATING TO THE POTENTIAL INTRODUCTION

OF NOVEL FEEDSTOCK SPECIES AND RISK OF INVASION...............................................................39

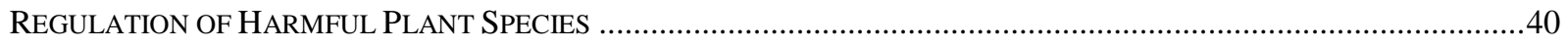

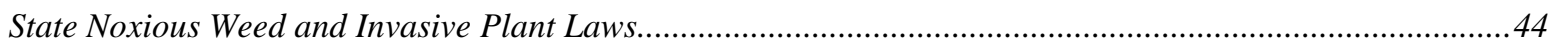

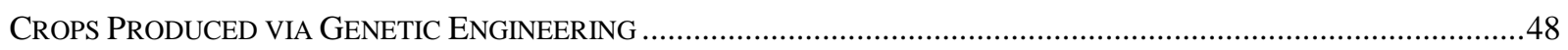

INCENTIVES AND SUBSIDIES FOR BIOENERGY PRODUCTION ..........................................................................51

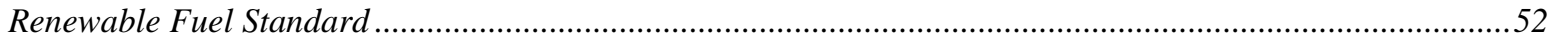

Biomass Crop Assistance Program .............................................................................................................54

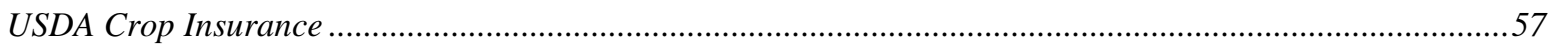

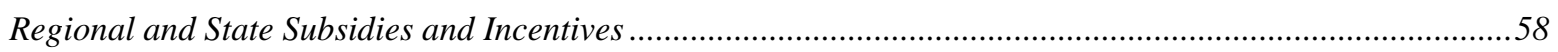

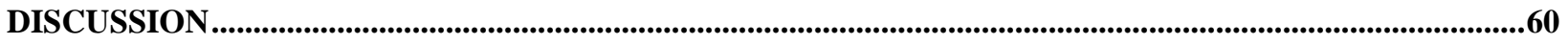

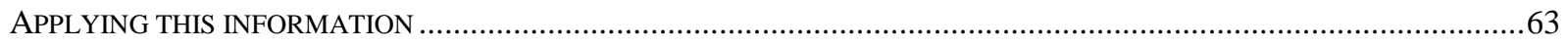

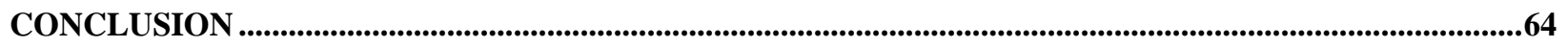

LITERATURE CITED .........................................................................................................................................65 


\section{LIST OF FIGURES}

Figure 1: Results of Australian Weed Risk Assessment application to various biofuel feedstocks. Blue lines indicate the transition between categories $(\leq 0=$ accept, 1-6=evaluate, $>6=$ reject $)$.

Figure 2: Flow chart describing the steps for a feedstock producer to select a low-risk biofuel feedstock, using the examples of Chinese silvergrass (Miscanthus sinensis), jatropha (Jatropha curcas) and switchgrass (Panicum virgatum) based on regulatory listing, native status, and weed risk assessment.

Figure 3: Flow chart describing the steps for a feedstock producer to reduce risk of invasion following introduction and potential eligibility for incentives/subsidies using the examples of Chinese silvergrass (Miscanthus sinensis), jatropha (Jatropha curcas) and switchgrass (Panicum virgatum), based on permitting requirements, best practices and regulations.

\section{LIST OF TABLES}

Table 1: Identified predictors of invasiveness in introduced species, their incorporation in four Weed Risk Assessment models, and whether the characteristic is sought in new biofuel feedstock crops.

Table 2: Summary of IUCN recommended biofuel feedstock selection and cultivation best practices (IUCN 2009).

Table 3: Noxious weed and weed seed status of selected candidate bioenergy feedstocks .....

Table 4: Invasion history, weed risk assessment scores, and potential legal and policy relevance for a selection of biofuel feedstock candidates. 


\section{Abstract}

Biofuels are being pursued for their potential greenhouse gas emissions benefits, among other reasons. In order to maximize productivity, avoid food-fuel conflicts, and minimize GHG emissions, many “advanced” biofuel feedstock crops, such as those desired by the aviation community, are under consideration based on traits, such as high biomass and/or seed production, tolerance of marginal cultivation conditions, and short generation times, that may also be predictors of potential invasiveness risk. Biofuel-related invasion risks can be mitigated through careful feedstock crop selection and cultivation techniques developed from the invasion science literature. Existing voluntary best practices and some state and federal regulatory requirements in the United States recommend and/or require the use of such risk mitigation strategies. However, other policies and programs allow or provide incentives for biofuel production without conditions requiring the use of these strategies. This study synthesizes information on the scientific knowledge of invasive species predictors and their use (or absence) in voluntary codes and United States regulatory frameworks and incentive programs. The study highlights the existing tools and approaches for assessing invasion risk and avoiding the introduction and spread of invasive species as a result of biofuel feedstock cultivation. A wellcoordinated combination of species restrictions, biosecurity requirements, and incentives for selection of less risky biofuel crops may effectively balance the desire for increased biofuel production while minimizing invasion risk.

Keywords: alien species, biomass, bioenergy, feedstock, invasion, non-native species, pest risk assessment, weed risk assessment 


\section{Introduction}

2 Recent studies indicate that biofuel species may pose a particular invasion risk because many of

3 the traits that are sought in biofuel feedstock crops to solve other issues facing the biofuels

4 industry may also predict higher likelihood of invasion risk (Raghu et al. 2006, Buddenhagen et

5 al. 2009, ISAC 2009). Some proposed biofuel feedstock species have become invasive in the

6 U.S. or elsewhere, and two, Arundo donax (giant reed) and Psidium cattleianum (strawberry

7 guava), are listed as among 100 of the worst global invaders by the International Union for the

8 Conservation of Nature (IUCN) for "serious impact on biological diversity and/or human

9 activities" (Lowe et al. 2000). The potential to introduce or exacerbate the spread of invasive

10 species therefore is an important consideration when selecting and cultivating bioenergy crops.

11 The challenge of feedstock selection and cultivation has become particularly important as fuel

12 producers and purchasers strive to avoid concerns about the use of food crops (which tend to be

13 well-known and rarely invasive) as biofuel feedstocks and to avoid the use of prime agricultural

14 land by selecting species that can tolerate marginal growing conditions. The aviation industry,

15 which anticipates being dependent on hydrocarbons for the foreseeable future, has shown

16 particularly strong interest in advanced biofuels from non-food crops, which led the Commercial

17 Aviation Alternative Fuels Initiative $\left(\mathrm{CAAFI}^{\circledR}\right)$ to work with the USDA on the development of a

18 "Feedstock Readiness Level” tool that maps out the development of a new bioenergy crop for

19 advanced biofuels (Steiner et al. 2012). However, while novel bioenergy crops provide the

20 potential to produce advanced, drop-in fuels in synergy with food production, these new crops

21 may pose a threat to native species and ecosystem functions if not properly screened for potential

22 invasion risk. 
1 Understanding the role played by species-specific traits, contextual factors, and their interactions

2 in determining invasion potential is important for biofuel feedstock crop selection and

3 cultivation. Once identified, these characteristics can be used to support risk assessment and

4 management to enable selection of biofuel feedstock crops that pose little risk of invasion and to

5 prevent the escape and establishment of species under cultivation. Risk assessment and

6 management tools may also determine the applicability of legal limitations and incentives that

7 influence when, where, and how bioenergy crop production occurs.

8 Weed Risk Assessment (WRA) tools have been developed to assess the environmental risks

9 associated with plant species through consideration of predictive species characteristics and

10 compatibility with ecological conditions (e.g., Pheloung et al. 1999, Daehler et al. 2004, Daehler

11 and Virtue 2010, Davis et al. 2010, Koop et al. 2012). Researchers are using WRA tools

12 extensively to evaluate candidate biofuel feedstock species (Daehler and Carino 2000, Barney

13 and Ditomaso 2008, Crosti et al. 2008, Gordon et al. 2008b, Nishida et al. 2008, Buddenhagen et

14 al. 2009, Crosti et al. 2010, Davis et al. 2010, Gassó et al. 2010, McClay et al. 2010, Davis et al.

15 2011b, Gordon et al. 2011, Gordon et al. ongoing).

16 WRA tools have both regulatory and non-regulatory uses. In a few countries, such as Australia,

17 WRA outcomes are used to determine whether to allow importation of non-native species that

18 are not already present. In the United States, on the other hand, WRA tools are used as a decision

19 support tool in few regulatory programs, and species with WRA outcomes indicating high risks

20 are not always subjected to regulatory restrictions intended to mitigate those risks. WRA tools

21 can also be used without a regulatory linkage, such as to identify or avoid high-risk species.

22 Voluntary best practice guidelines for biofuel production call for producers to consider WRA 
1 outcomes when selecting feedstock species; widespread adoption of these guidelines can reduce

2 invasion risk.

3 Feedstock crops may escape into the environment during cultivation or transport to a processing

4 facility. Invasions often exhibit time lag after introduction as the species becomes established

5 outside of cultivation (Nuzzo 1993, Kowarik 1995, Mack et al. 2000), offering an opportunity for

6 early detection and response (EDRR). EDRR effectiveness can be enhanced through the use of

7 cultivation practices such as buffer zones, monitoring, and financial assurance. Both voluntary

8 guidelines and some regulatory programs call for the use of such practices, which may vary by

9 geographic location, native status, and/or type of organism.

10 This study summarizes the science of terrestrial plant invasion prediction and its associated risk

11 assessment and risk management tools, and it assesses how these tools, findings, and

12 recommendations are incorporated into United States legal regimes affecting terrestrial biofuel

13 crop selection and cultivation. This analysis highlights the extent to which scientific evaluations

14 of invasion risk are used across various levels of regulation. It is not intended to recommend

15 exclusion of any individual feedstock species, but rather to identify gaps in policy that result in

16 inconsistent treatment of species that pose potential invasion risks. This study focuses its legal

17 analysis on the United States because applicable legal regimes differ substantially from country

18 to country, and few international regulatory tools are available for a unified approach to invasive

19 species prevention (Keller and Perrings 2011). Similar analyses are needed to understand the

20 interaction of invasive species prediction insights and regulatory requirements in other countries

21 and regions. Additional work is also needed to address the unique biological and legal

22 implications of aquatic species cultivation for biofuels, including algae, which are excluded from

23 the present study. 
A note on terminology:

2 The term “invasive species” is defined variously by different sources in different contexts (e.g.,

3 Richardson et al. 2000, Davis and Thompson 2001, Colautti and MacIsaac 2004, ISAC 2006,

4 European Commission 2008, Simberloff 2010, IUCN 2011). A clear definition of invasive

5 species is needed to avoid confusion and misplaced criticism (Davis et al. 2011a, Simberloff

6 2011). This study adopts the definition of invasive species used in Executive Order 13112

7 (1999), which identifies invasive species as: (1) not native to an ecosystem; and (2) species that

8 cause or are likely to cause economic or environmental harm or harm to public health when

9 introduced to a location where they are not native. Some researchers have suggested removal of

10 the requirement for harm from the definition of “invasive” species (Richardson et al. 2000, Pyšek

11 et al. 2004), and some of the literature identifying predictors of invasion may use alternate

12 definitions. However, non-native status and harm are common to many definitions in the

13 scientific and policy literatures and are the basis for regulation of these species; we therefore

14 adopt both non-nativeness and harm here. Without harm, there is little or no reason to address

15 invasive species risks with pre-importation evaluations, best management practices, or regulatory

16 constraints.

17 In addition, in this study, "bioenergy" crops are crops that are specifically grown for power

18 generation, process fuel, or conversion into liquid biofuels. “Cellulosic biomass” refers to

19 woody or herbaceous plant material that can be used for bioenergy purposes (e.g., pyrolysis,

20 Fischer-Tropsch), whereas “oilseeds” are crops for which the primary use is the extraction of oil

21 from mature seed for conversion to liquid fuels, such as for biodiesel or hydroprocessed esters

22 and fatty acids. 


\section{Predictors of Invasion}

2 Scientific knowledge about the potential risk posed by novel species can inform decisions about

3 the importation and use of biofuel feedstock species. Researchers have long attempted to

4 identify characteristics that predict whether a species is likely to become established and spread

5 when introduced to new locations (e.g., Lewontin 1965, Bazzaz 1986, Gray 1986, Vitousek

6 1986, Carson 1987, Rejmánek 1996, Rejmánek and Richardson 1996, Williamson and Fitter

7 1996b, Daehler 1998, Ellstrand and Schierenbeck 2000, Rejmánek 2000, Kolar and Lodge 2001,

8 Lockwood et al. 2001, Leishman et al. 2007, Moles et al. 2008, Bradley et al. 2009, Van Kleunen

9 et al. 2010). Many of the identified traits are interrelated; for example, a trait considered a

10 predictor in one study (e.g., rapid growth rate) may result from other factors (e.g., lack of

11 predators, environmental tolerance) used elsewhere as predictors. Predictive characteristics

12 include reproductive traits, species history, environmental tolerance, interactions/competition,

13 genetic factors, phylogenetic factors, and ecosystem characteristics. No single characteristic can

14 predict invasion risk; therefore, WRA tools combine a subset of identified characteristics -

15 generally, predictors that are easier to measure prior to introduction than other, interrelated

16 factors - to determine invasion potential. This section highlights traits linked to invasion

17 potential, focusing on those utilized in WRA systems. The subsequent section discusses how

18 these predictors are applied in WRA tools.

\section{Reproductive Traits}

20 Reproductive traits can enhance invasiveness by reducing barriers to reproduction in a new

21 location or by enhancing population growth. Short generation times (Rejmánek 1996, Rejmánek 
1 and Richardson 1996, Rejmánek 2000) and high seed/propagule production (Williamson and

2 Fitter 1996a, Kolar and Lodge 2001, Moyle and Marchetti 2006) rapidly increase the number of

3 individuals present in the new location. Early reproduction and high fecundity are sought in

4 biofuel feedstock crops, particularly in the case of oilseed crops (such as Camelina), to increase

5 fuel yield per hectare. Combined with repeated or widespread introductions, these traits may

6 increase feedstock crop propagule pressure and the likelihood of successful establishment

7 outside of cultivation.

8 Seed dispersal enhances the ability of a species to escape cultivation and spread. High seed

9 dispersal is not desirable for oilseed feedstock crops, but many candidate cellulosic biomass

10 feedstock species are grasses, which tend to have wind-dispersed seeds and therefore are more

11 likely to escape cultivation. Recent work has shown that both Miscanthus sinensis and M. $x$

12 giganteus exhibit long distance seed dispersal by wind, particularly at elevated wind speeds

13 (Quinn et al. 2011). To enable cultivation outside their home range, introduced biofuel feedstock

14 species also are likely to have generalist pollinators and other mutualists that may enhance

15 invasiveness potential. Self-compatible species and those with non-specialized pollinator

16 (Daehler 1998, Rejmánek 2000) and seed disperser (Rejmánek 1996, 2000) relationships are

17 more likely to reproduce and spread than self-incompatible species or those that rely on a

18 specialized mutualist for seed or pollen transport. The ability of seeds to form a seedbank will

19 allow the species to establish whenever conditions are favorable (Rejmánek 2000) and make

20 eradication difficult. While this trait is not sought in biofuel feedstock species, seed longevity

21 may be a useful consideration for reducing invasion risk.

22 Species that can reproduce vegetatively, especially from fragments, are likely to increase rapidly

23 and spread in a new location. For example, the biofuel feedstock species Arundo donax (giant 
1 reed) spreads during flooding events via dispersal of rhizome fragments (Bell 1997). Although

2 vegetative reproduction is not specifically sought in biofuel feedstock crops, its role in

3 facilitating invasion should be considered when selecting among possible feedstock species.

$4 \quad$ Hybridization with native species or among disparate populations of introduced conspecifics

5 may facilitate local adaptation (Ellstrand and Schierenbeck 2000, Mack et al. 2000).

6 Hybridization may contribute to the invasiveness of Sorghum almum (Columbus grass, a

7 congener of the potential biofuel feedstock species S. bicolor) and several Cardamine (cress)

8 species (in the Brassicaceae, the same family as Camelina) (Ellstrand and Schierenbeck 2000).

9 However, hybridization with less fit relatives may also reduce invasion potential. Intentional

10 hybridization also may influence potential invasiveness, but the direction of this influence will

11 depend on the traits sought through hybridization. Miscanthus $x$ giganteus is a sterile hybrid

12 bred for high biomass production that is considered less likely to be invasive than M. sinensis,

13 one of the parent species; thus, hybridization may be a negative or positive predictor of invasive

14 potential depending on whether the traits that arise from hybridization are specifically selected

15 for non-invasive characteristics (such as M. $x$ giganteus) or whether the hybridization results in

16 increased weedy or invasive characteristics. Sterile M. x giganteus is considered low risk;

17 however, recent efforts to generate a fertile-seeded M. x giganteus (Ross 2011) may result in a

18 high-risk version of this hybrid.

\section{Distribution and Historical Factors}

20 Distributional and historical factors provide clues to a species' behavior within and outside of its

21 native range that can indicate its likelihood of escape and spread. 
1 Species known to have invaded or become naturalized in new environments in the past are strong

2 candidates to do so in the future (Kolar and Lodge 2001, Lockwood et al. 2001, Moyle and

3 Marchetti 2006), even among widely varying environments (Lockwood et al. 2001). Multiple

4 biofuel feedstock candidate species have a history of invasiveness in the U.S. and elsewhere,

5 including Miscanthus sinensis (Chinese silvergrass), Arundo donax (giant reed), Pueraria

6 montana var. lobata (kudzu), Phalaris arundinacea (reed canary grass) and others (Lowe et al.

7 2000, Raghu et al. 2006).

8 Species abundance in the native range appears to predict abundance in new locations (Crawley

9 1987, Firn et al. 2011), suggesting that species that successfully dominate their existing habitat

10 for any reason are often able to translate their success to other environments. This correlation is

11 particularly strong for grasses (Firn et al. 2011), many of which are under consideration as

12 biofuel feedstock crops due to their excellent biomass production.

13 Domestication history may exacerbate or mitigate invasion potential. Cultivated species with a

14 long domestication history are often bred to reduce undesirable characteristics (Pheloung 1999,

15 Pheloung et al. 1999) and enhance rare traits that are not necessarily successful in the wild (e.g.

16 dwarfism, non-dispersing seeds to aid in automated harvesting, loss of seed dormancy) that may

17 reduce invasion potential (Gressel 2005, Warwick and Stewart Jr. 2005). Domestication of the

18 candidate feedstock species Phalaris arundinacea (reed canarygrass) does not seem to have

19 exacerbated invasiveness compared with undomesticated strains (Jakubowski et al. 2011).

20 However, other traits selected for in domestication, including generalist pollination, adaptation to

21 disturbed habitats, polyploidy, and high vegetative vigor, are shared between domesticated

22 species, agricultural weeds (Warwick and Stewart Jr. 2005), and invasive species affecting

23 natural areas (Daehler 1998, Rejmánek 2000, Yamashita et al. 2000, Grotkopp et al. 2002, Shea 
1 and Chesson 2002, Bradley et al. 2009, Van Kleunen et al. 2010, te Beest et al. 2011). Thus,

2 extensive domestication may reduce or increase invasion potential depending on the

3 characteristics selected for and the extent of selection/domestication.

4 Finally, species from taxa unrepresented in the native flora of the new location may also be

5 better invaders (Rejmánek 1996, Daehler 2001, Lockwood et al. 2001, Ludsin and Wolfe 2001,

6 but see Diez et al. 2008). Some candidate feedstock species may not have native congenerics in

7 their new location; such species could pose an enhanced risk of invasion in comparison to

8 species with native congenerics.

\section{Environmental Tolerance}

10 Species that tolerate a broad range of environments (Williams and Black 1993, Williams et al.

11 1995, Durand and Goldstein 2000, Yamashita et al. 2000, Moyle and Marchetti 2006), including

12 disturbed habitats (Yamashita et al. 2000, Shea and Chesson 2002, Bradley et al. 2009) and

13 locations with low resource availability (e.g., marginal lands, shade) (Pattison et al. 1998, Shea

14 and Chesson 2002) are more likely to be invasive than species with limited environmental

15 tolerance due to their ability to outcompete other species under a variety of conditions. Biofuel

16 proponents have suggested the use of biofuel feedstock species that tolerate a variety of growing

17 conditions and can be grown on "marginal” or non-prime agricultural land in order to avoid

18 displacement of food crops. Species selected on this basis may have increased likelihood of

19 escape from cultivation into the environment.

20 Broad ecological tolerance is often due to high phenotypic plasticity (the ability to adjust

21 physiology, resource allocation, or morphology based on local conditions), which itself is a 
1 predictor of colonizing ability (Bazzaz 1986, Gray 1986, but see Palacio-López and Gianoli

2 2011, Rejmanek 2011). Although recent work has questioned the ultimate fitness impact of the

3 high plasticity of invasive species, particularly in low resource environments (Davidson et al.

4 2011), highly plastic species that prosper under marginal conditions may perform even better

5 under high-resource conditions or have traits that are absent in the local flora and enable them to

6 take advantage of marginal conditions. Thus, highly plastic crops grown on marginal lands may

7 not stay on marginal lands. The candidate feedstock species Miscanthus sinensis has been

8 shown to tolerate a wide array of soil and moisture conditions, and conditions occupied in its

9 native range are different from those occupied in areas where it is invasive (Quinn et al. 2012),

10 which could indicate local adapation or high plasticity as a contributor to invasiveness. A study

11 of Triadica sebifera (Chinese tallow, a potential biofuel feedstock species) indicates that

12 invasive populations in North America have greater relative growth rate and greater allocation to

13 aboveground biomass and leaf area than in its Asian home range (Zou et al. 2007), suggesting a

14 flexible response to conditions in the new range that may confer an advantage over natives.

15 Climate change may favor species that can adapt to changes in resource availability. Some

16 proposed biofuel feedstock species have shown an ability to invade in part due to their tolerance

17 of conditions that may be found under climate change; the success of Pennisetum setaceum

18 (fountain grass) in invading a variety of habitats on Hawaii has been attributed to its broad 19 temperature tolerance (Williams and Black 1993).

20 Competitive Ability and Other Interactions 
1 Many invasive species adopt strategies to enhance their competitiveness in a variety of

2 environments (D'Antonio and Vitousek 1992, Mack et al. 2000, Levine et al. 2003). For

3 example, invasive species generally have higher growth rates than the native species (Grotkopp

4 et al. 2002, Shea and Chesson 2002, Van Kleunen et al. 2010), probably due to factors

5 previously discussed (including environmental tolerance), relief from herbivores and diseases,

6 and unique competitive characteristics such as allelopathy. Fast growth allows a species to crowd

7 out or shade its competitors and is considered highly desirable in bioenergy feedstock species.

8 Plants can improve their competitive ability and increase their potential invasiveness by

9 investing fewer resources to construct tissues (e.g., having high leaf area per unit mass)

10 (Williams and Black 1993, Williamson and Fitter 1996a, Pattison et al. 1998, Baruch and

11 Goldstein 1999, Durand and Goldstein 2000, Nagel and Griffin 2001, Smith and Knapp 2001,

12 Grotkopp et al. 2002, McDowell and Turner 2002, Maron et al. 2004) and maintaining storage

13 tissues underground (particularly those that enable resprouting). Climbers that shade or smother

14 other plants are likely to be invasive (Daehler 1998), as are those that form dense stands that

15 prevent native species from co-occurring with them (e.g., the potential biofuel feedstock species

16 Pueraria montana var. lobata (kudzu)).

17 Competition with native species can be influenced by other types of biotic interactions.

18 Introduced plant species generally experience a period of very low attack from herbivores,

19 parasites and pathogens that may provide a competitive advantage over native species that are

20 more heavily attacked (Schierenbeck et al. 1994, Torchin et al. 2003, Torchin and Mitchell 2004,

21 Hawkes 2007, Blumenthal et al. 2009). Pest resistance and/or the absence of local pests

22 generally are advantageous for biofuel feedstock species because they limit the need for 
1 pesticides and reduce the associated negative environmental effects and life-cycle greenhouse

2 gas emissions. However, these benefits may be offset by an increased risk of invasion.

3 Plants may also obtain a competitive advantage by causing direct damage to other species.

4 Species that cause damage to neighboring plants through parasitism, such as those in the genus

5 Striga, are likely to be effective invaders (Mohamed et al. 2006). Allelopathic plants exude

6 chemicals from foliage or roots that hinder the growth or germination of competitors. Introduced

7 allelopathic plants may have a particular advantage over native species in new environments

8 because native species may not have evolved tolerance to their allelopathic compounds (Prati

9 and Bossdorf 2004). Furthermore, allelopathy may occur through disruption of local

10 mutualisms, reducing performance of native species and thereby increasing the invaders'

11 competitive success. The invasive species Alliaria petiolata (garlic mustard) does not utilize

12 mycorrhizal fungi to assist nutrient uptake (which most plants do), and furthermore exudes a

13 chemical that interferes with the mycorrhizal relationships of neighboring tree seedlings (Stinson

14 et al. 2006), thus reducing competitor performance. Allelopathic traits are unlikely to be actively

15 sought in biofuel feedstock species; however, some Eucalyptus are under consideration as

16 biofuel feedstock species due to their rapid growth, and some Eucalyptus have allelopathic

17 effects (del Moral and Muller 1970, May and Ash 1990).

\section{Phylogenetic Factors}

19 Several meta-analyses have utilized phylogeny to identify taxa that are consistently

20 overrepresented among invasive species in order to utilize family or genus as a screening tool

21 (Crawley 1987, Daehler 1998, Rejmánek 2000, Kolar and Lodge 2001). Poaceae (grasses) and 
1 Fabaceae (legumes) are overrepresented in invasive floras (Daehler 1998), as are the

2 Brassicaceae (mustard family - e.g., Camelina, canola), which include a number of species that

3 are identified as highly invasive in the U.S. (Crawley 1987). A global analysis found these

4 families to be unusually widespread, whether native or introduced (Stohlgren et al. 2011). These

5 groups are likely overrepresented due to family-level traits that increase invasiveness, such as

6 wind-dispersed seeds (e.g., many grasses).

7 The phylogenetic position of many potential biofuel feedstock species may raise invasiveness

8 concerns, although species-level characteristics may be more important predictors of invasion

9 than this higher level information (Diez et al. 2008). A recent meta-analysis suggested that over

10 half of proposed biofuel feedstock species come from four highly weedy/invasive families: the

11 Euphorbiaceae (spurge family, e.g., Jatropha curcas), Fabaceae (including soybean, Pongamia,

12 Acacia, and others), and Myrtaceae (myrtle family, including Eucalyptus), and Poaceae

13 (Miscanthus, switchgrass, sweet sorghum, etc.) (Buddenhagen et al. 2009).

\section{Genetic Factors}

15 High genetic variability among individuals may predict invasion success (Bazzaz 1986, Gray

16 1986, Rejmánek 1996) by providing the raw material for rapid evolutionary change under novel

17 selective pressures as a result of range expansion, thus potentially enabling a species to invade

18 (Bazzaz 1986, Badyaev and Hill 2000, Badyaev et al. 2000, Mack et al. 2000, Sakai et al. 2001,

19 Maron et al. 2004). For example, in the proposed biofuel feedstock species Phalaris

20 arundinacea (reed canary grass), enhanced genetic variation due to multiple introductions has

21 led to enhanced plasticity, local adaptation, and invasiveness (Lavergne and Molofsky 2007). 
1 The intentional introduction of seed from multiple sources to develop crop seed stocks may

2 increase the risk of similar genetic changes in other biofuel feedstock species.

3 Chromosomal duplication (polyploidy), a common event in plants that can result in rapid

4 changes in species physiology, morphology and ecology, including colonizing ability, and can

5 mask the expression of detrimental traits, may be related to invasiveness (Pandit et al. 2011, te

6 Beest et al. 2011). A metaanalysis of 81 invasive species and over 2300 congeners (species in

7 the same genera as the invaders) indicated that polyploid species or populations of a species are

8 more likely than diploid species to be invasive, whereas species that are diploid are more likely

9 to be endangered (Pandit et al. 2011). Comparisons of native and invasive populations of the

10 same species with existing variation in ploidy levels in both locations show that invasive

11 populations are more likely to be dominated by variants with higher ploidy levels (te Beest et al.

12 2011). Polyploidy is not specifically sought in biofuel feedstock crops, but is easily measured

13 and could be used in screening potential feedstock species.

14 Cultivation of genetically modified biofuel feedstock species may pose unique invasion risks.

15 Genetically engineered (GE) organisms are not necessarily more likely to escape cultivation than

16 non-modified organisms, as many of the traits engineered into crop species facilitate success in

17 cultivation (e.g., herbicide resistance) rather than enhancing likelihood of escape into natural

18 areas. Traits that may increase invasiveness potential, such as resistance to pests or pathogens,

19 are already accounted for as predictors of invasion (see Table 1). Therefore, genetic engineering

20 per se does not predict invasiveness, although it may influence other predictive traits. GE crop

21 use may also exacerbate the risk of invasiveness in co-occurring species, as transfer of or

22 selection for traits such as herbicide-resistance may confer advantages on weedy species that

23 may prevent effective control in natural areas (Cerdeira and Duke 2006), resulting in a novel 
1 invasion risk. For example, the extensive, low-intensity use of herbicides on herbicide resistant

2 GE crops has resulted in selection for herbicide-resistance in the weed Sorghum halapense in

3 Argentina (Binimelis et al. 2009). On the other hand, GE seed stocks tend to be more pure than

4 naturally collected seed and may therefore reduce the unintentional introduction of contaminant

5 seeds that may cause new invasions (Cerdeira and Duke 2006). Nevertheless, GE crops may

6 warrant detailed assessment for invasion risk that may go beyond application of WRA tools

7 (Koop et al. 2012) to avoid causing or exacerbating the spread or impacts of invasive species.

\section{Ecosystem Characteristics}

9 No species can invade a new location unless it can tolerate and thrive in the new environment.

10 In addition to the ability of a species to respond to disturbance and tolerate a range of

11 environmental conditions, characteristics of recipient ecosystems - including but not limited to

12 diversity, disturbance regime, and climate - and their compatibility with the needs of a given

13 introduced species strongly affect invasion risk.

14 Ecologists have long theorized that highly diverse ecosystems are less easily invaded than

15 disturbed ecosystems due to high competition for resources and space among established natives

16 (e.g., Elton 1958, Kennedy et al. 2002). Plant community invasibility is affected by both

17 disturbance regime and the availability of bare ground (resources) on which new plants can

18 establish (Crawley 1987). On the other hand, a number of highly diverse communities have been

19 found to be vulnerable to invasion (Lonsdale 1999, Levine 2000, Lyons and Schwartz 2001,

20 Moyle and Marchetti 2006, Stohlgren et al. 2011), although this may depend on the individual

21 species that are present (van Ruijven et al. 2003). In addition, time since introduction may play 
1 an important role in the perceived relationship between abundance of invaders (invasion success)

2 and native species diversity; invaders may do well right after disturbance, followed by an

3 increase in native species diversity (Clark and Johnston 2011). Thus, disturbance regime and

4 species diversity may influence the ability of a new species to escape and invade a given

5 location.

6 Cultivation intentionally lowers ecosystem resistance to localized invasion of crop species: crops

7 are inherently introduced to locations with compatible climatic conditions, soils, possibly limited

8 pests and pathogens, and other factors, thus overcoming ecosystem barriers to invasion

9 (Richardson and Blanchard 2011). Biofuel feedstock species will be grown as crops and thus are

10 likely to successfully establish within cultivation sites. The use of diversity and disturbance

11 regime to predict escape from cultivation and potential invasion by biofuel feedstock species is

12 difficult due to the scale of intentional introduction and the mosaic of habitats and disturbance

13 regimes that the species may encounter in habitats surrounding cultivation sites.

14 Use of Invasiveness Predictors in Pre15 introduction Weed Risk Assessment

16 In practice, prediction of invasiveness is difficult because species have numerous traits that

17 enhance or reduce the risk that they will become invasive and because local environmental

18 conditions may influence species behavior. However, the retroactive definition of important

19 traits associated with invasive species described in the previous section has enabled development

20 of effective tools to assess invasion risk proactively (e.g., Pheloung et al. 1999, Daehler and

21 Carino 2000, Stohlgren and Schnase 2006, Parker et al. 2007, Koop et al. 2012). These tools 
1 were first developed and continue to be used to apply scientific knowledge to decisions about

2 whether and under what conditions importation of non-native plant species should be allowed

3 (Pheloung et al. 1999). Limits on importation are likely to be the most effective tools for

4 preventing the introduction or spread of invasive species, and in fact have been shown to produce

5 net economic benefits (Keller et al. 2006). These tools can be used to formally and consistently

6 predict invasion risk associated with biofuel feedstock species and thereby reduce the risks of the

7 industry as a whole. Biofuel producers can proactively use WRA tools to inform feedstock crop

8 selection and select low-risk feedstock species that minimize the environmental and economic

9 issues associated with cultivation of potential invasive species.

10 The Australian WRA tool (Pheloung et al. 1999) is the most widely used system for predicting

11 invasive species from among a pool of already established introduced species due to its accuracy

12 and ease of use. It categorizes species for rejection, acceptance, or further study based on the

13 answers to 49 questions about species-specific, climate matching, and other traits (Pheloung et

14 al. 1999); included predictors are summarized in Table 1). The major categories of criteria are:

15 domestication/cultivation history, climate and distribution, history of weediness, undesirable

16 traits (e.g., toxicity, spines), plant type, reproductive traits, dispersal, and likelihood of

17 persistence. The answers to these questions result in a single numerical score that is used to

18 categorize species as accept (score $\leq 0$ ), evaluate further (1-6), or reject ( $>6$ ).

19 The majority of the criteria in the Australian WRA are species-specific rather than Australia-

20 specific, and therefore the tool is readily adapted to other locations. Only Section 2 (climate and

21 distribution), and questions 4.10 (grows on infertile soils as found in Australia) and 8.05

22 (effective natural enemies present in Australia) need to be modified in order to use the tool in

23 other ecosystems. 
1 The Australian WRA model has been applied extensively to determine whether to allow

2 importation of introduced species and potential introductions in Australia (Australia Quarantine

3 and Inspection Service 2011) with rejection of 84\% of existing major and minor weeds (of those

4 rejected by expert opinion without use of the WRA) and only 7\% of non-weeds rejected. Nearly

5 a third of species (29\%) fell into the "evaluate further" category. This same model has also been

6 tested and found to be effective (with slight modifications) in New Zealand (rejected 93\% of

$7 \quad$ species categorized as weeds by expert opinion) (Pheloung et al. 1999).

8 Further refinements and modifications have been undertaken to improve the accuracy and utility

9 of the Australian WRA and adapt it for regions outside of Australia. These include changes to

10 adjust for local habitat matching (Daehler and Carino 2000). The Australian WRA has been

11 adapted by researchers for use in the Pacific Islands (Daehler et al. 2004, HPWRA 2010), and

12 the continental U.S. (Gordon et al. 2008b, Gordon et al. 2011, Gordon et al. ongoing), as well as

13 in Japan (Nishida et al. 2008) and the Mediterranean region (Crosti et al. 2010, Gassó et al.

14 2010). Daehler et al. (2004) developed a secondary decision tree for Hawaii and the Pacific

15 Islands that assesses species that fall into the "evaluate further" category under the modified

16 Australia WRA in order to accurately move those species into the "accept" or "reject" categories.

17 This added component rejects trees and tall shrubs that are shade tolerant and form dense stands,

18 are clearly bird or wind dispersed, and have a short generation time (less than four years).

19 Herbaceous species or low shrubs are rejected if they are reported agricultural weeds and are

20 unpalatable to grazers or known to form dense stands. Davis et al. (2010) suggest that secondary

21 screening may be important for species qualifying for "accept" as well as "evaluate further" in

22 order to reduce the potential for accepting a highly invasive species; their proposed follow-up

23 screens include post-introduction quarantine cultivation trials and monitoring. Two different 
1 metastudies have found that the Australian WRA is an effective screening tool across geographic

2 regions (with adaptations for climate matching and the other geography-specific questions

3 highlighted above) and suggest that Australian WRA species evaluations from one location can

4 be used with reasonable confidence for other areas with similar climate (Gordon et al. 2008a,

5 Chong et al. 2011), although the cross-regional correlation is more accurate for "major" invaders

6 than minor (Gordon et al. 2008a).

7 The Australian WRA heavily weights aquatic organisms as likely invaders (Pheloung et al. 1999)

8 because there are so many existing, successful aquatic invaders, but some modifications have

9 been proposed that reduce the bias against aquatic species (Gordon and Gantz 2011). New

10 Zealand has created an analogous risk assessment framework for aquatic plants that has been

11 modified for the United States and found 91\% accurate (Gordon et al. 2012). While this paper

12 only discusses terrestrial species, the potential for algal and other proposed aquatic biofuel crops

13 (e.g., duckweed, water hyacinth) to become invasive will need to be addressed in future analyses

14 for the same reason.

15 In addition to adaptations for local environmental conditions and secondary screening, efforts

16 have been made to adjust the scoring methodology to better reflect existing risk management

17 approaches. Daehler and Virtue (2010) utilized a standard risk assessment model structure,

18 grouping the Hawaii-adapted Australian WRA criteria into two categories - risk of introduction

19 and impacts (likelihood and consequences in risk assessment terms), and using a multiplicative

20 model to improve the accuracy (up to 91\% rejection of weeds). These adaptations/expansions of

21 the Australian WRA incorporate the Australian WRA criteria by reference or explicitly and

22 therefore are not included in Table 1. 
1 The Australian WRA system is simple to use and aims to use as little subjective evaluation as

2 possible. However, expert users may still disagree on important scoring traits (Pheloung et al.

3 1999, Davis et al. 2010); thus detailed justifications for scoring should be incorporated into

$4 \quad$ WRAs. The Australian government uses the system to determine whether to allow importation

5 of particular plant species and what, if any, conditions may be required for importation to occur.

6 The system is consistent with the International Plant Protection Convention (IPPC) (IPCC 1997)

7 and the Agreement on the Application of Sanitary and Phytosanitary Measures (SPS Agreement,

8 part of the General Agreement on Tariffs and Trade) (WTO 1994), which call on signatories to

9 protect plant resources from the spread of pests while minimizing interference with international

10 trade (Campbell 2001, Schrader and Unger 2003).

11 The USDA developed its own "weed-initiated” pest risk assessment (PRA) methodology

12 (APHIS 2004) intended to comply with international law governing restrictions on trade. PRA is

13 a broad term intended to encompass potential insect pests and other organisms; the USDA

14 “weed-initiated” PRA is a WRA methodology focusing on potential plant invaders. USDA's

15 weed-initiated PRA took into account many of the same predictors as the Australian WRA, but

16 was more qualitative and required more subjective evaluation by the user. Most recently, USDA

17 developed a new WRA tool that incorporates questions from the Australian WRA as well as

18 from other tools and sources (Koop et al. 2012). Like other WRA systems, the new USDA tool

19 groups traits associated with establishment/spread or impact. However, this tool also

20 incorporates Monte Carlo simulations to test how likely it would be that the outcome of the

21 analysis would change if the answers to questions for which there is high uncertainty (i.e., little

22 data) were different. This approach allows the user to identify confidence intervals for their

23 results to see how robust the analysis is (Plant Epidemiology and Risk Analysis Laboratory 
1 2012). The tool also estimates extent of potential range in the United States as well, based on

2 general ecological information about precipitation, general climate classification, and tolerance

3 of minimum winter temperatures (Plant Epidemiology and Risk Analysis Laboratory 2012).

4 In a direct comparison with the Australian WRA (adapted for the US), this tool shows similar

5 level of rejection of major invaders and improved acceptance of non-invaders. The predictors

6 utilized by the original USDA PRA tool and the new tool are identified in Table 1 . The USDA

7 intends to use the new tool as "the first in a series of defenses against invasive species" (Koop et

8 al. 2012) by enabling rapid screening of invasion risk to inform and feed into regulatory

9 processes (see "Regulation of harmful plant species" below).

10 Another quantitative, likelihood-by-consequences multiplicative model to assess weeds for the

11 U.S. as a whole was developed by Parker et al. (2007). This tool categorizes predictors into four

12 major groups: invasiveness potential (based on weediness/invasiveness history, reproductive

13 traits, palatability, responsiveness to and tolerance of environmental conditions),

14 geographic/climate matching potential, entry potential, and impacts potential. Scoring is based

15 on individual species predictors within each category, and the resulting scores are multiplied to

16 arrive at the final score. Species are then ranked by score rather than categorized as

17 accept/reject/evaluate. The predictors incorporated into this tool are indicated in Table 1.

18 Other weed risk assessment tools have been developed for use at the state and local level. In

19 Indiana, for example, the Invasive Plant Species Assessment Working Group has developed a

20 weed risk assessment protocol that specifically focuses on current impact, rate of spread,

21 introduction history, and habitat matching for the state. It also covers many of the same

22 biological predictors of invasion as the Australian WRA, including reproductive characteristics, 
1 competitive ability, and formation of a seed bank. Application of this tool to various introduced

2 species in Indiana can be found online (Indiana Dept. of Natural Resources 2011), but has no

3 regulatory implications. Likewise, Alaska's Natural Heritage Program utilizes a WRA form that

4 covers many of the same predictors as the Australian WRA (Carlson et al. 2008, Alaska Natural

5 Heritage Program 2011) and is used to rank invasiveness potential in Alaska on a scale of 0 to

6 100, but does not have a direct linkage to legal requirements.

7 The specific criteria from the scientific literature that are incorporated into several of the WRA

8 tools described previously are shown in Table 1, as well as whether the trait is actively sought in

9 biofuel feedstock species. The Australian WRA system has been the most widely used tool to

10 date, particularly for the assessment of potential biofuel feedstock species, and therefore the

11 following discussion of weed risk assessments relevant to biofuels focuses on application of the

12 Australian WRA system to biofuel feedstock species.

13 Of the seven most commonly used indicators (appearing in all four screening tools), four of the

14 criteria (high seed/propagule production, short generation time, broad environmental tolerance,

15 and preadaptation to a given climatic region) are traits that are also sought in biofuel feedstock

16 species. Of additional traits found in three screening tools, two (escape from herbivores and

17 tolerance of marginal lands) are sought in biofuel feedstock species. Only one predictor

18 commonly sought in biofuel feedstock species is not explicitly incorporated in the Australian

19 WRA - high competitive ability. However, this predictor is implied in some of the Australian

20 WRA criteria, such as questions in Section 3 on weediness. Climate matching is a key

21 component of most WRA systems (but see Koop et al. 2012), because a species introduced into

22 challenging conditions may have limited invasion opportunities. As crop species, biofuel

23 feedstock species will inherently be introduced to favorable locations. Therefore, climate 
1 matching may be of limited predictive use in the case of an intentionally introduced feedstock

2 species.

3 Domestication history is utilized in different ways in three WRA tools. Extensive domestication

4 is considered a low-risk trait for the purposes of the Australian WRA and the new USDA PRA

5 because crops are assumed to be selected for non-weedy traits (Pheloung 1999, Koop et al.

6 2012). However, due to high propagule pressure as a result of high reproduction and repeated

7 introductions (Williamson and Fitter 1996a), Parker et al. score weedy species already in

8 cultivation as more likely to become invasive (Parker et al. 2007). Only the original, qualitative

9 USDA tool current considers abundance in the home range as a predictor in its scoring system.

10 These WRA tools incorporate a subset of the traits that have been identified to predict

11 invasiveness, and they focus on criteria that are easily evaluated in advance of introduction.

12 Table 1 lists additional predictors that may be incorporated into predictive tools in the future.

13 Plasticity and resource allocation flexibility are not addressed explicitly in these four WRA tools,

14 although they may be implied by the inclusion of broad environmental tolerance. The ability to

15 respond to changes in resource availability due to climate change is specifically used as a

16 predictor in the Parker WRA model but not in the other tools. Relatedness to GE crops may be a

17 predictor because of the risk of receiving transgenes that facilitate invasion or hinder control

18 efforts, but this characteristic has not been incorporated into any of these WRA tools and may

19 require more detailed case-by-case risk assessment based on the GE traits involved and the

20 potential for outcrossing with related species. Ecosystem disturbance regime and diversity level

21 relationships are difficult to assess unless the assessment is focused on a very small area and are

22 likewise not included in the WRA tools covered here. Thus, there are traits that may be

23 considered voluntarily during feedstock species selection and/or that may be accommodated in 
1 voluntary best practices during cultivation that may not currently enter into formal weed risk

2 assessment.

3 Use of WRA Tools to Predict Invasion by 4 Biofuel Feedstock Species

5 Due to growing concern about the potential for introduction and spread of invasive species as a

6 result of biofuel feedstock production, a number of recent studies have used the Australian WRA

7 (adapted to the US or Europe, with or without refinements) to evaluate the invasive potential of

8 biofuel feedstock species (Daehler and Carino 2000, Barney and Ditomaso 2008, Crosti et al.

9 2008, Gordon et al. 2008b, Nishida et al. 2008, Buddenhagen et al. 2009, Crosti et al. 2010,

10 Davis et al. 2010, Gassó et al. 2010, McClay et al. 2010, Davis et al. 2011b, Gordon et al. 2011,

11 Gordon et al. ongoing). In all, 64 species identified by researchers to be under consideration as

12 biofuel feedstock crops have been evaluated at least once using the Australian WRA framework,

13 but very few have been analyzed with the other tools to date; therefore, this synthesis focuses on

14 evaluations using the Australian WRA. The accept, reject and evaluate categorizations for each

15 species are shown in Figure 1. The studies incorporated into Figure 1 cover a variety of

16 geographic regions, including the U.S. as a whole, Hawaii and the Pacific Islands, Florida, Italy

17 and Japan, as previous studies have suggested that Australian WRA evaluations are accurate

18 among regions with similar climates (Gordon et al. 2008a, Chong et al. 2011).

19 Assessment resulted in "reject" in at least one instance for 44 of the 64 considered species, while

2015 species had at least one "accept” evaluation (including species conditionally accepted

21 following an initial assessment of "evaluate" - Figure 1 lists the original "evaluate" score for 
1 these species). The assessments differ on specific scoring decisions, but rarely on outcomes. For

2 eight species, assessors disagree on the appropriate outcome; all of these disagreements entail

3 "evaluate" outcomes contrasting with outright reject or accept outcomes. For one species,

$4 \quad$ Panicum virgatum (switchgrass), assessments results in reject and conditional accept after

5 evaluation. 69\% of the potential biofuel feedstock species considered herein have at least one

6 reject score, which is consistent with Buddenhagen et al. (2009), who compared WRA scores of

740 potential biofuel feedstock species and 40 other, randomly selected introduced species and

8 found that the biofuel feedstock species scored significantly higher (statistically more likely to be

9 invasive) than the other introduced species. These results demonstrate the invasion potential of a

10 wide range of biomass feedstocks and the need to assess risk of invasiveness.

11 Post-Introduction Species Escape and 12 Spread

13 Even with the use of WRA to screen potential bioenergy feedstock crops, it is impossible to

14 totally eliminate the risk of introducing a problematic invasive species. The post-introduction

15 risk of invasion involves the combined probability of escape, spread, and resulting harm (Hails

16 and Timms-Wilson 2007).

17 Once a feedstock species has been selected and introduced to a new location for cultivation,

18 escape from cultivation can occur as a result of normal seed dispersal or pollen outcrossing or as

19 a result of specific cultivation activities. For example, the transport of intact seeds or

20 regenerative plant fragments from the point of harvest to the point of processing may

21 unintentionally result in dispersal to new locations along the transport route or at the point of 
1 unloading at the processing facility. Furthermore, the movement of vehicles to and from the area

2 of cultivation may result in inadvertent transport of plant propagules in mud on vehicle tire

3 treads or other unintended mechanisms. Other human-related sources of accidental transport

4 include "hitchhiking" (Stohlgren et al. 2011), such as on worker clothing or domesticated

5 animals.

6 Vegetative propagule dispersal can result from damage to plants capable of regenerating from

7 fragments of root or stem (e.g., Arundo donax) or, for example, underground or surface

8 spreading of clonal species that are able to resprout outside cultivated areas (e.g., Populus

9 species and many grasses). In addition, the spread of genetic material from an introduced species

10 can occur via pollen dispersal and successful hybridization with related species in the

11 surrounding environment, although the associated likelihood of resulting invasion is related to

12 the frequency and fitness of hybrids (Hails and Timms-Wilson 2007).

13 These escape routes can result in the establishment of naturalized populations of the plant that

14 can form the nucleus for spread into other areas. Each of these mechanisms for escape poses

15 concerns that can be at least partially mitigated through active risk management. In the biofuel

16 context, seedlings of some biofuel feedstock candidates with high scores on WRA assessments

17 have been observed to have escaped from bioenergy planting areas in Hawaii, leading the

18 authors to recommend implementation of mitigation practices to minimize invasion risk

19 associated with cultivation of these species (Daehler et al. 2012).

20 Once escape occurs, the next phase of invasion is spread from the initial point of establishment.

21 Many species experience a delay, or lag phase, between introduction and invasion (Nuzzo 1993,

22 Kowarik 1995, Mack et al. 2000). This delay may represent a period of cryptic (undetected) 
1 spread of the species (Carey 1996) or may reflect when suitable conditions become available for

2 spread (Mack et al. 2000). During this lag phase, detecting incipient invasions is difficult

3 because the escape may be comprised of a few, small individuals in a few suitable locations

4 (Carey 1996). Once the lag phase ends, invasion tends to occur in a "stream" along paths of

5 suitable habitat, rather than uniform spread outward from a single or several points (Carey 1996).

6 Knowledge of pathways for dispersal and spread can inform best management practices to

7 minimize likelihood of dispersal and improve monitoring and containment efforts.

8 Managing Invasion Risks Through

9 Voluntary Best Practices

10 Many industries use voluntary best practices to minimize risk of environmental damage, and

11 there are many sources for identifying best management practices (BMPs) to reduce the risks of

12 selecting or cultivating a species at high risk of becoming invasive. IUCN has created BMPs for

13 feedstock species selection and cultivation that apply to both governments and growers, and

14 include the use of WRA (IUCN 2009). The US has included many of the IUCN's government-

15 related BMPs in the National Invasive Species Management Plan (NISMP).

16 Preventing the introduction of invasive species is the easiest and most cost-effective strategy for

17 reducing the environmental and economic impacts of invasive species (NISC 2008). Prevention

18 can occur in the biofuel context by screening potential non-native feedstock species for invasion

19 risk prior to introduction and excluding those that present a high risk. The IUCN BMPs provide

20 guidance for governmental management of biofuel feedstock species risks, including strategic

21 guidance on species selection and regulatory requirements for non-native species introductions. 
1 For growers, the BMPs involve prospective analysis of potential environmental impacts of the

2 introduced species (Environmental Impact Assessment, or EIA), including a detailed WRA of

3 the proposed feedstock species. Both the WRA and the EIA can identify potential sources of

4 harm from the species under consideration or assure the producer, regulators, and potential fuel

5 purchasers that the feedstock species is low risk. The IUCN best practices relevant to pre-

6 importation decision-making for non-native species are summarized in Table 2.

7 NISMP recommendations also include incorporation of WRA into screening processes and

8 enhancement of quarantine and phytosanitary measures in accordance with the IPPC, the North

9 American Plant Protection Organization, and other programs (NISC 2008). The NISMP also

10 recommends the development of additional BMPs by stakeholders, thereby suggesting the use of

11 BMPs created by IUCN or other groups within the US (NISC 2008). These NISMP elements

12 indicate the intention to enhance consistency between US policy and internationally-recognized

13 BMPs.

14 WRA is also incorporated into other voluntary management systems, including the sustainability

15 criteria created by the Roundtable for Sustainable Biofuels (RSB) (Roundtable for Sustainable

16 Biofuels 2010). RSB's sustainability criterion 7.e requires that "biofuel operations shall prevent

17 invasive species from invading areas outside the operation site.” Strategies proposed by RSB for

18 fulfilling this criterion include not selecting known invaders as feedstock crops; using WRA

19 during the selection of a new feedstock species without invasion history; and following

20 monitoring, containment and mitigation best practices consistent with those put forth by the

21 IUCN. 
1 The use of WRA to identify and select low risk species may help feedstock producers to

2 minimize reliance on other BMPs to prevent invasion during cultivation and processing. Species

3 categorized as "evaluate further" by the WRA or that are introduced despite conclusions of

4 "reject" or "high risk" need to be monitored to ensure that they do not escape and spread, and

5 even some species that are scored as "accept" may warrant further evaluation after introduction

6 (Davis et al. 2010). Post-introduction management practices and related policy interventions

7 may provide additional protection to enable early detection and to prevent the spread of crops

8 that prove invasive after introduction.

9 "Early detection and rapid response" practices have been defined to reduce the risks of invasive

10 species escape and spread (e.g., NISC 2003), as have BMPs for crop cultivation and

11 management. Voluntary measures have been ineffective in other contexts in the absence of legal

12 requirements, and commentators have argued that voluntary BMPs alone are unlikely to prevent

13 biofuel-mediated invasions, as BMPs impose costs, and the likelihood of financial penalties for

14 the source of an escaped species is low (Low et al. 2011). However, some legal provisions

15 mandate the use of BMPs, which may increase their adoption, effective implementation, and

16 industry-wide acceptance.

17 The IUCN best practices (IUCN 2009) include BMPs for cultivation of bioenergy crops in order

18 to reduce the likelihood of escape and spread. Many of these practices are also incorporated into

19 the RSB Sustainability Criterion 7.e., and are recommended by research studies (Barney and

20 Ditomaso 2008, Davis et al. 2010, Byrne and Stone 2011, Lonsdale and Fitzgibbon 2011). Best

21 practices for prevention of escape focus on seed / propagule production and dispersal. Several

22 authors recommend the use of quarantined field trials similar to those used for transgenic crops 
1 (Barney and Ditomaso 2008, Davis et al. 2010, Lonsdale and Fitzgibbon 2011), and some

2 suggest using trials to develop management guidance for each species (Barney and Ditomaso

3 2008, Byrne and Stone 2011). Lonsdale and Fitzgibbon (2011) suggest more specific

4 management measures that include slowly scaling up plantings of novel species, monitoring,

5 preventing reproduction, and requiring the use of buffer zones around plantings, with additional

6 monitoring beyond the buffer zones. Buffer zones around crop plantings inhibit seed dispersal

7 and facilitate the detection of escaped crop offspring or associated pests (through the use of

8 indicator species) (IUCN 2009, Lonsdale and Fitzgibbon 2011). Other IUCN strategies for

9 limiting invasive species establishment and spread include low/no-till cultivation, fencing and

10 other barriers to reduce seed / propagule dispersal (IUCN 2009) (see Table 2). Similar

11 management measures are likely to be included in any management plan calling for 'site

12 hygiene' (e.g., Byrne and Stone 2011). Because natural seed dispersal may be difficult to control

13 once seeds mature (as in wind-dispersed grass species, such as Miscanthus), harvesting prior to

14 seed set is considered a best practice for cellulosic biomass crops to prevent escape from

15 cultivation (IUCN 2009) - however, this best practice cannot be applied to oilseed crops for

16 which the mature seed is the feedstock source. For such crops, IUCN best practices call for

17 minimizing transport of intact seeds (e.g., from oilseed crops) or other potentially regenerative

18 propagules, including transport routes as well as cultivation sites in monitoring plans, and

19 maintaining and cleaning vehicles to prevent accidental dispersal of propagules (IUCN 2009).

20 Rapid response to escaped organisms requires proactive detection techniques. Although

21 monitoring may require resources, the investment is likely to be worthwhile, as early detection of

22 escape can substantially reduce eradication costs (Rejmanek and Pitcairn 2002). A model

23 monitoring program encompasses the entire zone of intact propagule use, including nurseries, 
1 fields, transport routes, and initial processing sites. Early detection best practices promote the

2 use of both active and passive detection networks (by responsible parties and by organizations or

3 individuals that may fortuitously detect escaped organisms, respectively), and robust knowledge

4 management techniques (e.g., data sharing, training for monitoring and detection, learning from

5 past experiences) ( NISC 2003). Carey suggested that detection of new invasions is hindered by

6 the assumption of random dispersal/concentric spread (Carey 1996). Using knowledge of

7 ecological compatibility may enable a feedstock producer to better focus its own monitoring

8 efforts toward likely habitats for establishment of escaped individuals near the sites of crop

9 activities. Monitoring efforts should take into account habitat specificity as well as dispersal

10 pathways.

11 Upon detection of an escape from cultivation into the environment, a response strategy is needed.

12 Rapid assessment of the extent of spread, selection among potential actions, and rapid response,

13 supported by advance preparation such as personnel training and availability, response manuals

14 and action plans, and funding availability, are critical to the success of post-escape control

15 efforts, as elaborated in the National Invasive Species Council (NISC) guidelines for EDRR

16 (NISC 2003). Immediate eradication is the most effective action to prevent establishment or

17 spread, particularly when the area where the species initially colonized is small (Rejmanek and

18 Pitcairn 2002). Barney and DiTomaso (2008) suggest requiring proactive management plans to

19 provide for complete eradication of feedstock species should they prove invasive. However,

20 once spread has begun, containment and mitigation may be the only options to manage the

21 potential harm caused by an incipient invader (Rejmanek and Pitcairn 2002). The main best

22 practice (and incentive for other BMP use) is to establish a contingency fund to cover costs 
1 associated with any mitigation or control efforts resulting from cultivation of the bioenergy crop

2 (IUCN 2009).

3 Regulations, Policies and Incentives

4 Relating to the Potential Introduction of

5 Novel Feedstock Species and Risk of

6 Invasion

7 While voluntary measures are important, regulatory systems also play an important role in

8 preventing harm from invasive species. This section reviews key elements of the complex and

9 interwoven system of federal and state laws, and regulations governing and providing incentives

10 for bioenergy cultivation to identify where and how they restrict the importation or cultivation of

11 invasive or potentially invasive species.

12 Federal agencies are required to consider and avoid the introduction and spread of invasive

13 species in the United States. Executive Order 13112 requires agencies to manage how their

14 actions may affect the introduction and spread of invasive species, regardless of taxon, habitat, or

15 type of impacts. To comply with the Order, federal agencies must identify actions that "may

16 affect the status of invasive species,” and they cannot authorize, fund, or carry out discretionary

17 actions likely to cause or promote the introduction or spread of invasive species without first

18 determining that the benefits "clearly outweigh" the potential harm and taking "all feasible and

19 prudent measures" to minimize the risks, with exceptions for national security (Executive Order

20 No. 13112 1999). 
1 The NISC (established by Executive Order 13112) and its associated Invasive Species Advisory

2 Committee (ISAC) have identified biofuel feedstock species screening as an important agency

3 responsibility. The most recent NISMP calls for the development of screening processes to

4 evaluate the invasiveness of plants moving in international trade (NISC 2008). ISAC's 2009

5 white paper (ISAC 2009) identified actions specifically related to biofuels that may "cause or

6 promote the introduction or spread of invasive species," and it calls upon agencies to evaluate

7 biofuel feedstock species invasiveness and to use and promote genotypes and cultivars that are

8 unlikely to escape from cultivation, become established in the environment, or become invasive

9 (ISAC 2009). Development and implementation of the new USDA WRA tool is a substantial

10 step forward to meeting the goal set out in the NISMP and for enabling agencies - including but

11 not limited to USDA - to assess feedstock species invasion risk and promote low-risk feedstock

12 species. Regarding post-introduction invasion and spread, some agencies, such as the Federal

13 Highway Administration, have created guidance to enhance detection of invasive species and

14 limit their spread (Federal Highway Administration 2006); however, no federal agencies have

15 created guidance to date specifically to address the invasion risks associated with biofuel

16 feedstock crop cultivation.

\section{Regulation of Harmful Plant Species}

18 Federal and state agriculture and weed laws are the most applicable to biofuel cultivation, as

19 these laws limit plant importation, transportation, and cultivation, including for biofuel feedstock

20 species. The Department of Agriculture (USDA) primarily regulates harmful plants under two

21 laws that authorize regulation of "noxious" weed species. The Plant Protection Act (PPA) (2011

22 ed.) authorizes USDA to prohibit or restrict importation, exportation, and interstate movement of 
1 plants, plant products, certain biological control organisms, Noxious Weeds, and plant pests if

2 necessary to prevent the introduction into the United States or the dissemination of a plant pest or

3 Noxious Weed within the United States. The Federal Seed Act (FSA) (Federal Seed Act 2011

4 ed.) authorizes USDA to regulate import of and trade in seeds and prohibits the transportation of

5 Noxious Weed seeds in interstate commerce.

6 Together, the PPA and FSA restrict the importation, transportation, and cultivation of federally

7 listed Noxious Weed and weed seed species. Like the definition of invasive species under

8 Executive Order 13112, a species must cause harm to be added to the federal Noxious Weed list:

9 under the PPA, a plant species must cause harm to agriculture, irrigation, navigation, natural

10 resources, public health, or the environment (Plant Protection Act 2011 ed., at $\S 7702$ ). USDA’s

11 Animal and Plant Health Inspection Service (APHIS) evaluates whether species meet this

12 definition and may add potentially harmful species to the list. The FSA defines a Noxious Weed

13 as any plant “recognized as noxious” by USDA or a state (Federal Seed Act 2011 ed.at §1562).

14 USDA and each state have established lists of prohibited and restricted Noxious Weed seeds.

15 The FSA prohibits seed shipments (i.e., transport or sale of seed) that exceed tolerances for the

16 presence of Noxious Weed seeds (zero for prohibited Noxious Weed seeds and a maximum

17 tolerance for restricted weed seeds) (Federal Seed Act 2011 ed. at $\S 1571$ ), and prohibits any

18 import of agricultural or vegetable seeds containing Noxious Weed seeds (Federal Seed Act

192011 ed.at § 1581). Under the PPA, a permit is required to import, trade, transport, or release any

20 Noxious Weed into the environment (USDA Regulations 2011 ed.-d, at § 360.100). APHIS will

21 not issue a permit that would result in dissemination if the weed's destructive potential

22 outweighs its probable benefits, or for other reasons (USDA Regulations 2011 ed.-d, at $\S$ 
1 360.304). Permits for the release of Noxious Weeds into the environment must include

2 conditions necessary to prevent dissemination into the environment (USDA Regulations 2011

3 ed.-d, at $\S 360.303)$. These conditions are developed on a case by case basis and may include

4 inspections to determine "whether the facilities [ ] are adequate to prevent noxious weed

5 dissemination” and to ensure compliance with permit conditions (USDA Regulations 2011 ed.-d,

6 at $\S$ 360.303). A biofuel producer that allows a listed noxious feedstock species escape from

7 cultivation into the environment would be subject to civil and criminal penalties (Plant

8 Protection Act 2011 ed., at $\S 7734$ ) and could be required to destroy its crops (USDA

9 Regulations 2011 ed.-d, at $\S 360.305)$. In addition, APHIS may hold, treat, or destroy an article

10 imported into or moving in interstate commerce if necessary to prevent the dissemination of a

11 noxious weed that is new to or not prevalent and widely distributed in the United States (Plant

12 Protection Act 2011 ed., at $\S$ 7714). APHIS is also authorized to take remedial and emergency

13 action to control and eradicate Noxious Weeds and plant pests after they are released into the

14 environment - or may require owners to do so at their own cost (Plant Protection Act 2011 ed., at

$15 \S 7714-15$, USDA Regulations 2011 ed.-d, at § 360.106).

16 Species are not subject to these restrictions under either the PPA or FSA unless they are listed as

17 a Noxious Weed or weed seed. In recent years, APHIS has used its PRA tool as the basis for its

18 Noxious Weed listing decisions (APHIS 2004, 2010), and will likely use the new WRA tool in

19 the future, as indicated in recent assessment documents (APHIS 2009b). As a result, future

20 Noxious Weed and weed seed listing decisions - at least those under the PPA - are likely to be

21 strongly influenced by USDA WRA outcomes, among other factors such as presence and

22 economic importance. As weediness is only one of several considerations in the listing process, 
1 the federal Noxious Weed list is not a comprehensive listing of weedy species, and many species

2 with high WRA scores will not be listed.

3 In practice, current Noxious Weed and weed seed lists include few biofuel species with high

4 scores under the Australian WRA methodology (Table 3). As a result, most potential biofuel

5 species are not currently subject to related prohibitions on importation, commerce, or release into

6 the environment, regardless of potential invasiveness. APHIS may add potentially invasive

7 feedstock candidates to the Noxious Weed lists in the future as species evaluations proceed,

8 either as a result of requests for review or in reaction to proposals for cultivation, particularly for

9 species listed as noxious by one or more states.

10 Recognizing that potentially noxious, but unlisted, plants are eligible for import but not yet

11 present in the United States, APHIS recently used its PPA authority to proactively use WRA to

12 identify and prevent the importation of nursery stock. Any species listed as "Not Authorized

13 Pending Pest Risk Analysis” (NAPPRA) (APHIS 2011b) cannot be imported. Species can be

14 petitioned for removal from the list, in which case APHIS will conduct a risk analysis and

15 thereafter allow (subject to general or specific restrictions) or prohibit importation. Depending

16 on the results of the risk assessment, APHIS could also list the species on the federal Noxious

17 Weed list. A species is added to the NAPPRA list if APHIS determines, based on scientific

18 evidence, that it is host to a plant pest or is "a plant pest or Noxious Weed that is of potential

19 economic importance to the United States and not yet present in the United States, or present but

20 not widely distributed and being officially controlled” (USDA Regulations 2011 ed.-c, at $\S$

21 319.37-1). In practice, data to support listing will be captured on a short data sheet, and WRA is

22 not required for NAPPRA listing. Further guidance on this process - some of which may be 
1 forthcoming (APHIS 2011b) - and practical experience with implementation will clarify the

2 operation of this program.

3 Unlike general Noxious Weed listing, which does not consider native status, NAPPRA listing is

4 limited to potentially harmful plants that are not present or not widespread in the United States.

5 NAPPRA thus echoes the elements of the federal (and international) definition of a quarantine

6 pest, but also that of an invasive species. However, many potential biofuel feedstock species are

7 native to all or part of the United States (e.g. Panicum virgatum) or already present in the United

8 States (e.g. Camelina sativa), so it is not surprising that the initial list of NAPPRA species does

9 not include any species currently under consideration as a biofuel feedstock crop. As a result,

10 NAPPRA is likely to be most applicable to non-native species that are identified as feedstock

11 candidates in the future. For example, the potential cellulosic biomass feedstock species $A$.

12 saligna is not on the NAPPRA list (APHIS 2011c), but its congeneric Acacia hockii is listed. If

13 A. hockii had compatible biofuel characteristics and was considered for biofuel use in the future,

14 a WRA and a PRA would be required before it could be imported. Species that are hosts for

15 plant pests may also be listed and subject to PRA before importation; for example, potential

16 biofuel feedstock Psidium spp. is on the NAPPRA list because it is a host plant for Anoplophora

17 chinensis, a quarantine pest (APHIS 2011a). The associated PRA will focus on the risk of

18 introducing the pest rather than whether the species is itself harmful, and therefore will not rely

19 on the WRA tools discussed here.

\section{State Noxious Weed and Invasive Plant Laws}

21 States have enacted laws analogous to the PPA and FSA, generally administered by state

22 agriculture departments. Every state has its own seed law and most states have enacted Noxious 
1 Weed laws. Some states have also enacted species-specific laws, independent of or in addition to

2 existing Noxious Weed lists, to address harmful plants of particular concern.

3 State seed laws closely follow the structure of the FSA by limiting the commercial sale of seed

4 containing listed species of "prohibited" and "restricted” weed seeds (USDA 2010). Similarly,

5 while specific provisions differ by location, state Noxious Weed laws follow the federal structure

6 and are based on lists of Noxious Weeds. Both seed and weed laws prohibit or restrict the

7 import, introduction, purchase, sale, transportation, propagation, or other uses of listed species.

8 State Noxious Weed laws also go beyond the PPA by imposing direct burdens on landowners to

9 control Noxious Weeds (Environmental Law Institute 2004).

10 State species lists differ greatly in both form and content. Some states, including Alabama,

11 North Carolina, South Carolina, and Vermont, incorporate the federal Noxious Weed list by

12 reference and supplement it with additional species of local concern; other states have developed

13 their own unique lists that may or may not include species that are on the federal list. State lists

14 may be extremely short; for example, Delaware lists only four species (Delaware Department of

15 Agriculture 2011 ed.). Other states have lengthy lists of species in multiple categories associated

16 with specific management goals. Montana classifies its listed weeds into five categories, each of

17 which corresponds to a management outcome. Priority 1 A species are subject to statewide

18 eradication, education, and prevention efforts, while Priority 2B species are widespread and

19 management must be undertaken by local weed districts for eradication or containment where

20 not abundant (Montana Department of Agriculture 2010).

21 Species are most likely to be listed in locations where they are likely to thrive (and are therefore

22 likely to become invasive). Triadica sebifera (Chinese tallow) - a candidate bioenergy crop in 
1 the southern US (Breitenbeck 2008) - is a listed noxious species in several southern states where

2 it grows most quickly, but is not listed elsewhere. Likewise, Arundo donax (giant reed) is listed

3 as a Noxious Weed in several arid states in the Southwest (see Table 3). Some state legislatures

4 have supplemented Noxious Weed lists by creating species-specific restrictions that apply to

5 species of particular concern. For example, Louisiana has enacted a law declaring T. sebifera to

6 be a noxious plant that may be destroyed wherever found (Louisiana statutes 2011 ed. at §1791).

7 Some states have additionally enacted laws restricting the release of invasive species. Such laws

8 are unique to the state level, as no federal laws directly restrict the use, transport and cultivation

9 of invasive plants in the private sector. Like Noxious Weed laws, many state invasive species

10 laws restrict importation, transportation, and propagation only of listed species. However, some

11 state invasive species laws use a "clean list" approach that bars the importation or release of

12 nonnative species unless and until specifically authorized by the responsible state agency. These

13 invasive species laws may be administered by state departments of environmental protection or

14 by natural resource agencies rather than by departments of agriculture and may focus more on

15 species affecting natural areas than on agricultural weeds. If so, invasive species lists may

16 contain different species than Noxious Weed lists, which historically have focused on

17 agricultural weeds (Quinn et al. 2013).

18 Florida enacted a law to address invasion risk associated with bioenergy development in

19 response to a 2005 proposal to produce giant reed (Arundo donax) as a bioenergy crop. The law

20 adopts a clean list approach that restricts the cultivation of any non-native plants for "fuel

21 production or purposes other than agriculture” (Florida Statutes 2011 ed., at §581.083). The law

22 requires a special permit from the Florida Department of Agriculture and Consumer Services 
1 (FDACS) to plant more than two contiguous acres of non-native or genetically engineered plants,

2 unless FDACS has determined that the species is not invasive. Permits require the use of

3 biosecurity measures and include financial incentives to prevent escape into the environment

4 during or after production. FDACS issues permits only if it determines that feasible measures

5 can be taken to prevent the spread of the plant into neighboring ecosystems. Permits must

6 include conditions for project design and operation that include but are not limited to traps to

7 prevent escape through ditches or drainage, measures to prevent spread by seed, a fallow area to

8 prevent spread into adjacent areas, and cleaning requirements of equipment used on the site

9 (FDACS regulations 2008, at §5B-57.011). If a special permit expires or if the permit-holder

10 ceases to meet permit conditions, the permit-holder is required to immediately remove and

11 destroy the plants subject to the permit and to notify FDACS within 10 days (Florida Statutes

122011 ed., at §581.083). This law also incorporates special financial conditions to address the risk

13 of abandonment and ensure that escapes of non-native species can be eradicated or controlled,

14 regardless of listing status. Permit applications must indicate the cost of removing and

15 destroying the planting. Unless exempted by FDACS, permit-holders must maintain a bond or

16 certificate of deposit of at least 150 percent of the cost estimate but not more than $\$ 5,000$ per

17 acre unless necessary to protect public health, safety, and welfare (FDACS regulations 2008, at

18 §57.011, Florida Statutes 2011 ed., at §581.083). The bond is held by the state and can be used

19 to fund removal of the plants in the event of abandonment or if the permit-holder violates other

20 permit conditions (FDACS regulations 2008, at §57.011).

21 Determination of potential invasiveness is crucial to effective implementation of Noxious Weed

22 and invasive species restrictions under both federal and state law. For "clean list” systems like

23 the Florida biomass law, the state must determine whether a species can be allowed entry and 
1 what, if any, restrictions may be required to minimize the possibility of escape. For traditional

2 Noxious Weed laws and other laws based on a "dirty list," the state must proactively identify

3 potential invaders for which listing is justified. The manner in which state agencies consider and

4 implement WRA tools thus plays a substantial role in determining the efficacy of these

5 regulatory programs. Statutes and regulations rarely require WRA tools to be used or provide

6 guidance for their deployment. As a result, implementation of WRA at the state level, like the

7 sophistication of Noxious Weed lists, differs from state to state. However, little specific

8 information is available on whether and how such tools are used in the regulatory context, and

9 most state-specific WRA information comes from non-regulatory sources (e.g., Gordon et al.

10 2008b, 2010, Gordon et al. 2011). In addition to uncertainty over WRA implementation, the

11 substantial differences from state to state in the restrictions associated with listing mean that a

12 case-by-case determination is required to determine the potential applicability of state noxious

13 and invasive species laws to a given biofuel candidate species.

\section{Crops Produced via Genetic Engineering}

15 There is a great deal of interest in optimizing biofuel production through development of

16 genetically engineered feedstocks (e.g., Xie and Peng 2011). APHIS-Biotechnology Regulatory

17 Services (a different branch of APHIS than Plant Pest and Quarantine, which manages Noxious

18 Weeds) is the primary regulator of environmental releases of GE plants (Office of Science and

19 Technology Policy 1986). APHIS biotechnology regulations "govern the introduction

20 (importation, interstate movement, and release into the environment) of certain GE organisms

21 termed 'regulated articles.' Regulated articles are essentially GE organisms which might pose a

22 risk as a plant pest” (APHIS 2008). Regulated articles include organisms altered or produced 
1 through GE that are or may be plant pests or that incorporate material from listed species of

2 donors, recipients, or vector agents that are plant pests (USDA regulations 2011 ed.-b, at $\S$

3 340.1). Parasitic plants are the only plant species currently included in the list of organisms that

4 are or contain plant pests, but donor or vector material from listed species could be used in the

5 biofuel context.

6 In 2008 APHIS proposed a rule to substantially revise the biotechnology regulations to address

7 potential Noxious Weed risk of GE organisms, as well as plant pest concerns, by enabling

8 review, risk assessment, and regulation of these organisms (APHIS 2008). This proposed change

9 would clarify that GE plants would be subject to APHIS regulation due to concerns about their

10 invasiveness and ensure that weed risk is considered under these regulations. After receiving

11 comments from the public, APHIS has not finalized the proposed regulatory changes, and

12 potential timeframe and revisions are uncertain (APHIS 2009a). Pending final action on this or

13 other revisions of the regulation, GE bioenergy crops that meet the definition of a "regulated

14 article” are regulated under the current APHIS biotechnology regulations. In practice, potential

15 GE bioenergy crops including GE eucalyptus have been subject to APHIS oversight (ArborGen

16 2011).

17 Movement or release of regulated articles into or within the US requires APHIS authorization in

18 the form of notification or a permit (USDA regulations 2011 ed.-b, at § 340.0-340.1). Regulated

19 articles can be introduced through notification if they are non-weedy plants with a stable genome

20 that do not include genetic material that causes production of infectious agents, viruses, toxic

21 substances, or products for industrial use. Neither Noxious Weeds nor plants that APHIS

22 determines are weedy in the location proposed for introduction can be introduced by notification. 
1 Regulated articles introduced by notification must meet performance standards, which provide

2 protection against escape as a result of shipment, mixing with other plant materials, vectors, or

3 persistence after completion of field trials (USDA regulations 2011 ed.-b, at § 340.3).

4 Regulated articles that do not meet the criteria for notification may be eligible for permits to

5 allow importation, movement, or release (USDA regulations 2011 ed.-b, at § 340.4).

6 Importation and movement permits for GE crops contain permit conditions that producers must

7 follow to minimize the possibility of escape into the environment, and accidental releases must

8 be reported to APHIS. Applications for environmental release permits must describe the

9 procedures, processes, and safeguards proposed to "prevent escape and dissemination of the

10 regulated article," among other elements. APHIS may carry out environmental assessment as

11 required by the National Environmental Policy Act (NEPA) when determining whether to issue

12 some permits for environmental release. If approved, environmental release permits for

13 production of GE biofuel crops will contain measures permittees must take to prevent escape and

14 establishment of species in the environment. Permits for environmental releases also require the

15 submission of field test reports and notification to APHIS upon accidental or unauthorized

16 release, or upon discovery that the organism has different characteristics from those listed in the

17 permit (USDA regulations 2011 ed.-b, at § 340.4). APHIS can take remedial measures, such as

18 quarantining or destroying the regulated articles, upon failure to follow the requirements for

19 introduction (USDA regulations 2011 ed.-b, at § 340.1).

20 GE plant permitting and notification requirements do not explicitly incorporate WRA tools or

21 outcomes, except insofar as Noxious Weeds are ineligible for notification. This is unsurprising

22 given that genetic engineering is not a consistent predictor of invasion or incorporated into any 
1 WRA tool, as discussed previously. More detailed, case-by-case assessment may be merited to

2 determine the potential weediness of GE plants (Koop et al. 2012). In practice, environmental

3 assessments carried out for environmental release permits consider weediness and invasion risk;

4 for example, environmental assessments carried out during GE eucalyptus permitting have

5 considered invasion risks associated with eucalyptus generally and as genetically modified

6 (ArborGen 2011 pp. 21-22). Moreover, the GE regulations provide for performance

7 requirements and permit conditions to mitigate associated invasion risks. Thus, while WRA

8 tools may not be incorporated explicitly into the GE regulations, APHIS biotechnology

9 assessment and approval requirements are proactive and likely to ensure assessment of invasion

10 risk for GE bioenergy feedstocks that are regulated articles.

11 The GE permitting requirements, like those for Noxious Weed release discussed earlier,

12 substantially overlap with monitoring and management recommendations identified in the

13 scientific literature and in voluntary BMPs. While the application of GE permitting requirements

14 to advanced feedstock crop cultivation is currently limited, these regulations may become more

15 relevant in the future as genetic engineering is increasingly applied to feedstock crops other than

16 corn and soybeans.

\section{Incentives and Subsidies for Bioenergy Production}

18 Federal and state governments have established a variety of programs to increase the production

19 of energy from nontraditional sources, including bioenergy production. These programs provide

20 incentives to increase propagation by providing markets for bioenergy or subsidies for bioenergy

21 production. Many biofuel-related programs, such as the 'blenders' credits' for the use of 
1 ethanol, biodiesel, and alternative fuels (U.S. Code 2014 ed.-b), focus on the final fuel product

2 and are silent on crop selection and management. However, access to other programs is

3 conditioned on the use (or avoidance) of certain species. These programs may directly influence

4 feedstock species selection, and WRA tools and outcomes may be incorporated into these

5 programs to ensure that they do not inadvertently promote the use of high-risk species. This

6 section focuses on programs that are likely to influence the use of particular species or categories

7 of bioenergy feedstocks for advanced biofuels.

\section{Renewable Fuel Standard}

9 The National Renewable Fuel Standard Program (RFS2), administered by the Environmental

10 Protection Agency (EPA), requires refiners, importers, and other obligated parties to blend four

11 specified categories of "renewable fuels" into gasoline and diesel transportation fuels (EPA

12 Regulations 2014, at §80.1406). Renewable fuels must be produced from "renewable biomass,"

13 which includes planted crops, trees, crop and tree residues, "slash and pre-commercial thinning,"

14 algae, and other materials. "Crop residues" include invasive species biomass removed for

15 invasive species control, and "pre-commercial thinning" includes "vegetative material” removed

16 to promote tree growth - including invasive species (EPA Regulations 2014, at §80.1401).

17 Unless otherwise exempt, renewable fuels also must have lifecycle greenhouse gas emissions

$1820 \%$ or more below baseline emissions, with particular requirements depending on the type of

19 renewable fuel (EPA Regulations 2014, at §80.1401). A fuel only qualifies as renewable if EPA

20 has determined that the feedstock and processing pathway used to create it meets or exceeds this

21 threshold (EPA Regulations 2014, at §80.1416 and 1425). Species that are not approved for RFS

22 qualification can still be used to produce fuels, but the resulting fuel does not provide a credit 
1 toward meeting RFS requirements. Therefore, RFS provides incentives for the production of

2 fuels from species with approved production pathways without preventing use of non-approved

3 species.

4 The application of RFS2 to existing invasive species biomass could benefit invasive species

5 control efforts, but the primary impact of the RFS2 program on invasive species will likely arise

6 from intentional cultivation for biofuel production. To date, EPA has evaluated and approved

7 fuel pathways arising from various species and categories of renewable biomass, including corn,

8 soybeans, sugarcane, "switchgrass and miscanthus," Camelina sativa, Arundo donax,

9 Pennisetum purpureum, and other specific species and generic feedstocks, including certain

10 categories of wastes and residues, each of which can be processed to produce several types of

11 renewable fuels. Feedstock species that are not currently covered by existing, qualified

12 pathways, such as Jatropha, could be evaluated and considered for approval in the future through

13 a petition process (EPA Regulations 2014, at §80.1416) should the evaluations demonstrate they

14 meet the minimum GHG threshold. EPA has already approved several new pathways through

15 the petition process and others have been proposed or are under review (EPA 2011b).

16 The Energy Independence and Security Act (EISA), which authorized the RFS2 Program, does

17 not require the use of WRA in the implementation of the RFS2 program. However, Section 204

18 of EISA requires consideration of invasiveness as part of EPA's periodic evaluations of the

19 Program. EPA has done so in its initial triennial report to Congress (EPA 2011a). Regulatory

20 programs maintained by other agencies may limit the cultivation of potentially invasive

21 feedstocks that can be used to generate renewable fuels. For example, it would be unlawful to

22 cultivate a federal listed Noxious Weed species in the United States even if the feedstock met the 
1 minimum life cycle GHG threshold qualifying it under the RFS2 program. Furthermore, EPA

2 has suggested that WRA tools be used and that BMPs be incorporated into selection and

3 cultivation plans to address invasion risks, particularly in the case of perennial grasses and

4 woody crops (EPA 2011a).

5 EPA required the implementation of BMPs in its recent approval of a pathway for production of

6 elephant or napier grass (P. purpureum) and giant reed (A. donax). Unless fuel producers or

7 importers can demonstrate that there is no significant likelihood that their plants will spread

8 beyond the planting area, they must obtain EPA approval of a Risk Management Plan (RMP)

9 that incorporates BMPs throughout feedstock production, management, transport, collection,

10 monitoring, and processing (EPA 2013). The BMPs should, inter alia, include provisions to

11 mitigate risks of escape and dispersal, including incorporation of traits that reduce invasion risk

12 (e.g., seed sterility), as well as a closure plan that includes early detection and rapid response and

13 that provides for destruction and removal of the feedstock from the growing area (EPA

14 Regulations 2014 at §80.1450(b)(1)(x)(A)). In addition to the RMP, producers or importers also

15 must meet other criteria, including obtaining a letter from USDA with conclusions about whether

16 the proposal presents a significant likelihood of spread beyond the planting area and whether

17 financial mechanisms are recommended to cover potential remediation costs should the plants

18 escape from the intended planting areas (EPA Regulations 2014 at $880.1450(\mathrm{~b})(1)(\mathrm{x})(\mathrm{A})$ ).

\section{Biomass Crop Assistance Program}

20 The Biomass Crop Assistance Program (BCAP) is a voluntary program that provides financial

21 incentives to farmers and forest landowners within a designated "project area" to assist in the

22 establishment, maintenance, cultivation and transportation of biomass for conversion into energy 
1 or biobased products. Project areas are established based on proposals submitted to USDA by

2 either a group of producers or a facility that converts the biomass into heat, power, a biobased

3 product or a liquid biofuel. USDA pre-approval of the project area is required for producers to

4 receive establishment or annual payments. Among other limitations, known or potentially

5 invasive or noxious species (USDA Regulations 2011 ed.-a, at § 1450.2) are explicitly ineligible

6 for establishment or maintenance payments (USDA Regulations 2011 ed.-a, at § 1450.2, U.S.

7 Code 2014 ed.-aat $\S 8111(a)(4))$ but are eligible for matching payments, subject to the limitations

8 in federal, state or local law, and consistent with Executive Order 13112 (USDA Regulations

92011 ed.-a, at §1450.103(a)(iii))

10 For BCAP purposes, the Farm Service Agency (FSA), with the Natural Resources Conservation

11 Service, the Agriculture Research Service and the Animal Plant Health Inspection Service (all

12 agencies within USDA) reviews the feedstock species proposed by BCAP project area applicants

13 and determines invasiveness and noxiousness, in consultation with other appropriate federal or

14 state departments and agencies, federal and state Noxious Weed and invasive plant lists, and

15 NEPA analyses. Although the FSA has not yet systematically incorporated WRA tools to date to

16 determine actual and potential invasiveness and noxiousness, the 2014 Farm Bill revised

17 BCAP's definition of eligible crop to exclude "species or varieties of plants that credible risk

18 assessment tools or other credible sources determine are potentially invasive” (113th Congress

192012 ; S. 954 at $\S$ 9009), thereby directly approving the use of WRA tools to assess biofuel

20 feedstock species invasiveness for this program.

21 CCC and the FSA have finalized a Programmatic Environmental Impact Statement (PEIS) for

22 BCAP (USDA Farm Service Agency 2010) as well as project-specific Environmental

23 Assessments (EAs) (USDA Farm Service Agency 2011, 2012). These analyses consider a range 55 
1 of impacts of program implementation, including invasion risk as informed by published WRA

2 studies, and impose a variety of mitigation and monitoring requirements, such as producer

3 education, site-specific conservation plans, and buffers, to minimize negative impacts to

4 biological resources. BCAP project proposals associated with planting species considered in the

5 PEIS, including perennial switchgrass, forage sorghum, and hybrid poplar and willow, generally

6 will not require additional review, while proposals to use other feedstock species require site-

7 specific EA. To date, FSA has issued two EAs for Miscanthus $x$ giganteus production (USDA

8 Farm Service Agency 2011, 2012), each of which requires the establishment and maintenance of

9 a minimum 25 feet of setback or border around a giant Miscanthus stand and prohibits planting

10 giant Miscanthus within approximately 1,300 feet of any known Miscanthus sinensis or

11 Miscanthus sacchariflorus to limit the potential for cross-pollination resulting in viable seed.

12 One of the EAs requires the use of only the sterile "Illinois Clone" variety of giant Miscanthus

13 within the proposed project areas, approval of all cultivars through the Ohio Seed Improvement

14 Association's Quality Assurance program, and a seed sampling program to determine the on-

15 going sterility of seeds produced from the acres within the project areas (USDA Farm Service

16 Agency 2011). The other EA requires the use of only the sterile variety of giant Miscanthus

17 known as Freedom ${ }^{\mathrm{TM}}$ Giant Miscanthus within the proposed project area, with all rhizomes

18 appropriately tagged and meeting the certification conditions of the Georgia Crop Improvement

19 Association minimum standards for Miscanthus (USDA Farm Service Agency 2012).

20 To date, USDA has approved eleven project areas to support a variety of biomass crops,

21 including "mixtures of perennial native grasses and forbs, such as Switchgrass, Big Bluestem,

22 Illinois Bundleflower and Purple Prairie Clover” (in Kansas, Missouri, and Oklahoma), the

23 sterile "Illinois Clone” of Miscanthus x. giganteus (in Arkansas, Missouri, Ohio, and 
1 Pennsylvania), Camelina (in Oregon, Washington, California, and Montana), and hybrid poplar

2 trees (in Oregon) (USDA 2011a).

3 Based on the project areas approved to date and the rules in place for collection and harvesting of

4 eligible materials, it appears that the BCAP program is and will remain limited to native and

5 low-risk species. The recently enacted congressional text supports this perspective by explicitly

6 providing that WRA tools can be used to assess potential invasiveness, but given the detailed

7 assessments carried out during the NEPA process for BCAP project proposals to date, their

8 incorporation may offer limited additional value, except in the context of species for which such

9 analyses are not available in the literature or about which little is known.

\section{USDA Crop Insurance}

11 The development of crop insurance is a key source of risk reduction for farmers. In 2011, the

12 USDA Risk Management Agency’s Federal Crop Insurance Corporation insured 265 million

13 acres of crops for a total value of $\$ 114.1$ billion (USDA/RMA 2012). Recently, USDA

14 announced a new pilot program for "Actual Production History” crop insurance for Camelina

15 sativa in selected counties in Montana and North Dakota (Federal Crop Insurance Act 2011, at $\S$

16 1523(f), USDA 2011b). Under the program, a grower's yield is insured against loss due to

17 adverse weather, fire, insect and plant diseases, and some natural disasters. Growers under

18 contract with a biofuels processor are eligible for the program. If this pilot program becomes

19 permanent and other crop insurance programs are established for dedicated bioenergy crops, the

20 availability of such insurance would likely provide incentives for growers to switch to new

21 crops. The current regulation does not address potential invasiveness in defining eligibility, nor

22 is WRA currently used to determine the development of insurance tools for bioenergy crops. 
1 However, it is conceivable that insurers would consider invasion risk as a financial concern,

2 particularly in cases where financial bonds are required to mitigate risk.

\section{Regional and State Subsidies and Incentives}

4 States have established biofuel incentive and benefit programs that are analogous to those in

5 Federal law. This section reviews two examples of programs - the California low-carbon fuel

6 standard (LCFS) and Oregon biofuel subsidies - that are silent on invasive or non-native status,

7 and two programs - Reinvest in Minnesota - Clean Energy (RIM-CE) and the Regional

8 Greenhouse Gas Initiative (RGGI) - that contain limits on eligibility of non-native species.

9 The LCFS is analogous to RFS2 and seeks reductions in the carbon intensity of transportation

10 fuels in California (Executive Order - Low Carbon Fuel Standard 2007, California Air Resources

11 Board regulations 2011 ed.). It requires regulated parties to meet yearly average carbon intensity

12 requirements for their fuels (California Air Resources Board regulations 2011 ed., at § 95482(a),

13 95484). The table of fuel carbon intensities currently only includes biofuels derived from corn,

14 soybeans, and sugarcane (California Air Resources Board regulations 2011 ed., at § 95486), but

15 the regulations do not limit the LCFS based on biological criteria, and regulated parties can

16 propose new fuel pathways based on life cycle carbon intensity values. Pathway evaluation

17 under the LCFS does not incorporate invasiveness assessment.

18 Oregon is one of many states that have created financial benefits for bioenergy production

19 without incorporating limitations based on invasion risk. In 2007, it enacted a package of biofuel

20 subsidy programs, including a tax credit for producers and collectors of biofuel raw materials, a

21 property tax exemption for biofuel production facilities, demand drivers including requirements 
1 for the state to use biofuels, an RFS2-like program, and other provisions (Oregon Legislative

2 Assembly 2007). These programs are intended in part to stimulate the cultivation of oilseed

3 crops for biodiesel, but none requires the use of native or non-invasive feedstock species.

4 On the other hand, Minnesota's RIM-CE law conditions qualification for bioenergy subsidies on

5 the use of native species. RIM-CE offers payments in exchange for long-term guarantees, via

6 easements, that agricultural land will be used to produce native bioenergy crops. Among other

7 requirements, easements must limit agricultural crop production to native perennial bioenergy

8 crops and may allow for nonnative perennial prairie or pasture established by September 1, 2007

9 that meets other objectives of the RIM-CE program (Reinvest in Minnesota Clean Energy

10 Program 2011, subd. 5). RIM-CE payments to landowners are tiered to provide the highest per-

11 acre value for "diverse native prairie and perennials” (Reinvest in Minnesota Clean Energy

12 Program 2011, at subd. 7). The base-level payment for planting one native perennial grass or

13 woody species is $80 \%$ of estimated market value; payments increase with the planting of

14 additional species and for plantings that address specific local environmental benefits (Minnesota

15 Board of Water and Soil Resources 2008). Thus, RIM-CE conditions benefits explicitly on

16 native status and biodiversity, thereby ensuring that the state will not financially support the

17 cultivation of invasive species and rendering WRA unnecessary.

18 Carbon offset projects may provide funding for biomass production, and one regional effort has

19 limited the use of invasive species for this purpose. RGGI caps and gradually reduces the

20 allowable carbon dioxide emissions from fossil fuel-fired electrical generating units in

21 participating states. Among other methods, regulated power plants can meet part of their

22 compliance obligations by sponsoring afforestation projects (i.e., creating new forest lands) to 
1 sequester carbon outside of the electricity sector (RGGI 2005), including through biomass

2 projects based on woody species. A qualifying afforestation project uses "mainly native species

3 and avoids the introduction of invasive non-native species” (RGGI 2008). Determination of

4 which species are considered "native" or "invasive non-native" in a particular state, and whether

5 proactive WRA is required prior to cultivation, depends on that state's implementation of other

6 laws and programs - most notably, state invasive and noxious plant laws.

\section{Discussion}

8 Bioenergy feedstock species could be selected for characteristics that would also increase the

9 risk of invasiveness; these characteristics include rapid growth, high seed production, broad

10 ecological tolerances including tolerance of marginal growing conditions, or escape from or

11 resistance to pests. Existing studies using the Australian WRA to evaluate biofuel species under

12 consideration for introduction to various countries indicate that bioenergy feedstock species are

13 more likely, when compared to non-feedstock species, to have a relatively high risk for invasion,

14 thus potentially harming the economy and environment.

15 A variety of interdependent restrictions and incentive programs affect feedstock species

16 selection. Direct restrictions on the importation, trade, and cultivation of species are primarily a

17 function of federal and state Noxious Weed provisions, GE crop cultivation restrictions, and

18 other state laws. These laws generally apply to agricultural cultivation generally rather than to

19 bioenergy production in particular.

20 Despite consistent suggestions from the scientific literature and warnings from NISC's advisory

21 committee (ISAC 2009), the federal government and the states have yet to comprehensively 
1 integrate WRA tools or approaches into regulations and policies focused on or affecting biofuel

2 selection or cultivation. In a few cases, including GE crop production, importation of species on

3 the NAPPRA list, and cultivation in the few states that use a "clean list" approach to non-native

4 plant regulation, risk assessment may be required prior to importation or cultivation of non-

5 native species. WRA is not proactively required prior to importation or cultivation in the

6 remaining programs, although many of these programs incorporate some form of WRA to

7 determine whether listing and associated restrictions are warranted.

8 In practice, USDA has published few evaluations of biofuel feedstock candidates conducted

9 under either its old or new risk assessment tools, and many non-native bioenergy feedstock

10 candidates are not listed as Noxious Weeds at either federal or state levels despite Australian

11 WRA scores indicating substantial invasion potential (Table 4). Further, many potential

12 feedstock species are ineligible for NAPPRA listing due to their widespread presence in the US.

13 As a result, many non-native feedstock species with high WRA scores currently can be imported

14 and cultivated without limitations. The NISMP (NISC 2008), EPA (EPA 2011a), and multiple

15 NGO's (e.g., IUCN 2009, Roundtable for Sustainable Biofuels 2010) recommend the proactive

16 use of WRA analysis to assess non-native feedstock candidates and to reduce potential

17 environmental harm resulting from biofuel development by avoiding the importation and

18 cultivation of candidate species that present a high risk of economic or environmental harm.

19 All direct biofuel incentive programs rely upon Noxious Weed listing and other restrictions on

20 importation and cultivation to avoid inadvertently supporting the cultivation of potentially

21 invasive bioenergy feedstock species, and this reliance is crucial for incentive programs without

22 independent eligibility criteria. The current set of interlocking regulatory programs depends on 
1 the cooperation of multiple agency actors to effectively prevent invasion; for example, to

2 determine eligibility for RGGI afforestation offsets, a state might consult its Noxious Weed and

3 invasive plant lists or request a WRA from USDA or another expert authority rather than carry

4 out an independent risk analysis. While agencies need to work together to prevent invasion (as

5 outlined in the NISMP), programs have disparate direction and priorities and therefore may not

6 reach identical conclusions on the appropriate regulation of a given species. For example, while

7 it would be inappropriate to provide incentives for cultivation of a harmful species that is

8 widespread in part, but not all, of the United States, that species would be ineligible for inclusion

9 on the NAPPRA list, which is limited by USDA regulation to species "not yet present in the

10 United States, or present but not widely distributed and being officially controlled.” Thus,

11 regulatory determinations under one regulatory program may not necessarily generate

12 restrictions that are appropriate to others.

13 Some, but not all, bioenergy incentive programs restrict eligibility based on invasive or native

14 status. For example, approval of a BCAP project requires environmental assessment that includes

15 consideration of species- and/or cultivar-specific invasion risk based in part on WRA or PRA

16 outcomes, thereby limiting eligibility for establishment or maintenance payments to native or

17 non-invasive species, cultivars, and hybrids. Recently adopted language in the 2014 Farm Bill

18 further strengthens consideration of invasion potential by endorsing WRA for determining

19 potential invasiveness under this program - the first time Congress, rather than an agency, has

20 explicitly supported the use of WRA as a decision support mechanism. When incentive

21 programs (such as BCAP) incorporate independent assessments of invasion potential based on

22 WRA outcomes, they reduce the risk of inadvertently providing incentives to cultivate 
1 potentially invasive species that are not otherwise regulated by Noxious Weed lists or other

2 importation and cultivation restrictions..

\section{Applying this information}

4 The preceding discussion shows that there are a variety of relevant legal frameworks in place

5 that may govern and affect feedstock species selection, but these frameworks do not

6 comprehensively restrict the importation or cultivation of potential invasive species. As a result,

7 the use of best practices to reduce invasion risk associated with cultivation is crucial to

8 effectively avoid the introduction and spread of invasive species in the United States as a result

9 of biofuel development. In some instances, such as for Noxious Weed permits, GE crop permits,

10 or non-native species releases in states with “clean list” laws regarding bioenergy or species

11 introductions, the use of best management practices may be required by Federal or State law.

12 Elsewhere, however, application of best practices such as those outlined by the IUCN and in the

13 NISMP to facilitate EDRR and reduce the risk of a detrimental invasion by a new plant species is

14 mostly voluntary (e.g., as part of the RSB sustainability criteria). Therefore, most of the

15 responsibility for feedstock species selection and BMP implementation lies with feedstock

16 producers and processors.

17 The patchwork of requirements and opportunities can make it seem as if the selection process

18 and pursuit of best practices to reduce invasion risk is complicated. However, explicit

19 consideration of a few key decision points can reduce the risks of introducing or cultivating a

20 potential invasive species and can also lead to qualification for incentive programs that can

21 facilitate producer activities. 
1 While this study does not provide new tools for assessing invasiveness, it highlights the existing

2 tools and approaches for assessing invasion risk and avoiding the introduction and spread of

3 invasive species as a result of biofuel feedstock cultivation. To facilitate the use of this

4 information, we have synthesized the information from this study into two flow charts (Figure 2

5 and 3) that integrate the information on pre- and post-introduction invasion risk management and

6 outline the steps involved in selecting or cultivating a low-risk biofuel feedstock species based

7 on weed risk assessment, species regulation, and recommended best practices. The flow charts

8 use three bioenergy feedstock candidates, Miscanthus sinensis, Jatropha curcas, and Panicum

9 virgatum, as examples; however, these charts are not intended to imply any universal

10 recommendations about the use of specific species. These flow charts are intended to provide

11 the basic outlines of a procedure for feedstock selection and implementation of best practices but

12 are not exhaustive and should not be construed as legal advice. These charts provide some

13 guidance to help biofuel feedstock producers understand how to effectively comply with existing

14 legal restrictions and incorporate the best practices and emerging scientific understanding to

15 minimize invasion risk.

\section{Conclusion}

17 As society pursues advanced renewable energy sources, such as the alternative drop-in

18 transportation fuels desired by the aviation community, novel bioenergy crops are likely be

19 introduced and/or cultivated as biofuel feedstocks. These crops will likely express characteristics

20 such as high growth rates, tolerance of marginal conditions, and other traits predictive of high

21 invasion risk, and this risk needs to be managed. This review of how US legal systems consider

22 and address biofuel invasion risks reveals a complex patchwork of partially interlocking 
1 restrictions on, and incentives for, bioenergy production. Under existing restrictions, only listed

2 species and categories of high risk feedstock candidates, such as GE crops, are subject to

3 comprehensive regulation or WRA prior to introduction; however, some programs consider

4 invasiveness proactively for particular purposes. Where invasion risk is not comprehensively

5 managed by laws and regulations prior to introduction, as in the U.S., the use of voluntary BMPs

6 created by IUCN and other groups (which uniformly call for incorporation and use of WRA) and

7 implementation of EDRR programs are crucial to drive selection of low-risk feedstock species

8 and to reduce the risk of introducing or allowing escape and spread of new invasive species. The

9 NISMP recognizes the importance of these initiatives; it outlines joint agency efforts to expand

10 monitoring, evaluation, and control efforts (including identification of gaps in management and

11 control strategies, treatment of invaded areas and increased cleaning programs) to reduce

12 invasive species impacts in the US. Such coordination on EDRR programs and associated

13 implementation of proactive WRA in existing regulatory frameworks may promote selection of

14 native and noninvasive feedstock species and improve cultivation methods. A well-coordinated

15 combination of species restrictions, biosecurity requirements, and incentives for selection of less

16 risky biofuel crops, consistent with the approach outlined for all non-native species by the

17 NISMP, may effectively balance the desire for increased biofuel production while minimizing

18 invasion risk.

19 Literature Cited

20 113th Congress. 2012. Agriculture Reform, Food, and Jobs Act of 2013: S. 954, § 9009.

21 Abhilasha, D., N. Quintana, J. Vivanco, and J. Joshi. 2008. Do allelopathic compounds in invasive Solidago canadensis s.l. restrain the native European flora? Journal Of Ecology 96:993-1001. 
Alaska Natural Heritage Program. 2011. Non-native plant species biographies (invasiveness column). Plant Invasiveness Risk Forms / Weed Risk Assessment Forms.

APHIS. 2004. Weed-initiated pest risk assessment guidelines for qualitative assessments. USDA/APHIS, Raleigh, NC.

APHIS. 2008. Importation, Interstate Movement, and Release into the Environment of Certain Genetically Engineered Organisms. Available at http://www.aphis.usda.gov/brs/fedregister/BRS_20081009.pdf. Federal Register 73:60008-66048.

APHIS. 2009a. Issue Paper 1: Scope of the proposed Part 340 regulations and which GE organisms should be regulated.

APHIS. 2009b. Lygodium microphyllum (Old world climbing fern), Lygodium japonicum (Japanese climbing fern), and Lygodium flexuosum: weed risk assessment. Rev. 05. Available at http://www.aphis.usda.gov/plant_health/plant_pest_info/weeds/downloads/wra/lygodium -spp.pdf. USDA/APHIS, Riverdale, MD.

APHIS. 2010. Update of Noxious Weed Regulations. Federal Register 75:68945.

APHIS. 2011a. List of NAPPRA Candidates for Host Plants of Quarantine Pests. Available at: http://www.aphis.usda.gov/import_export/plants/plant_imports/Q37/nappra/downloads/N APPRA1stNoticeList-CandidateHostPlants.pdf.in U. APHIS, editor.

APHIS. 2011b. Plant Import - Importation of Plants for Planting (Quarantine 37) Federal Register 76:31172-31210.

APHIS. 2011c. Plants for Planting Quarantine Pest Evaluation Data Sheets. Available at: http://www.regulations.gov/contentStreamer?objectId=09000064812637f0\&disposition= attachment\&contentType=pdf. USDA, APHIS.

ArborGen. 2011. Permit application 11-052-101rm received from ArborGen: Field testing of genetically engineered Eucalyptus grandis x Eucalyptus urophylla. Draft Environmental Assessment. Available at: http://www.aphis.usda.gov/brs/aphisdocs/11_052101rm_pea.pdf. USDA Biotechnology Regulatory Services.

Australia Quarantine and Inspection Service. 2011. AQIS Import Conditions Database (ICON): http://www.aqis.gov.au/icon32/asp/ex_querycontent.asp.

Badyaev, A., and G. Hill. 2000. The evolution of sexual dimorphism in the house finch. I. Population divergence in morphological covariance structure. Evolution 54:1784-1794.

Badyaev, A., G. Hill, A. Stoehr, P. Nolan, and K. McGraw. 2000. The evolution of sexual size dimorphism in the house finch. II. Population divergence in relation to local selection. Evolution 54:2134-2144.

Bais, H. P., R. Vepachedu, S. Gilroy, R. M. Callaway, and J. M. Vivanco. 2003. Allelopathy and exotic plant invasion: from molecules and genes to species interactions. Science 301:1377-1380.

Barney, J. N., and J. M. Ditomaso. 2008. Nonnative Species and Bioenergy: Are We Cultivating the Next Invader? BioScience 58:64-70.

Baruch, Z., and G. Goldstein. 1999. Leaf construction cost, nutrient concentration, and net $\mathrm{CO}_{2}$ assimilation of native and invasive species in Hawaii. Oecologia 121:183-192. 
Bazzaz, F. 1986. Life history of colonizing plants: some demographic, genetic, and physiological features. Pages 96-110 in H. Mooney and J. Drake, editors. Ecology of Biological Invasions of North America and Hawaii. Springer-Verlag, New York, NY.

Bell, G. 1997. Ecology and management of Arundo donax, and approaches to riparian habitat restoration in Southern California. Pages 103-113 in J. Brock, M. Wade, P. Pysek, and D. Green, editors. Plant Invasions: Studies from North America and Europe. Blackhuys Publishers, Leiden, The Netherlands.

Binimelis, R., W. Pengue, and I. Monterroso. 2009. "Transgenic treadmill": Responses to the emergence and spread of glyphosate-resistant johnsongrass in Argentina. Geoforum 40:623-633.

Blair, A. C., S. J. Nissen, G. R. Brunk, and R. A. Hufbauer. 2006. A lack of evidence for an ecological role of the putative allelochemical (+/-)-catechin in spotted knapweed invasion success. Journal Of Chemical Ecology 32:2327-2331.

Blossey, B., and R. Notzold. 1995. Evolution Of Increased Competitive Ability In Invasive Nonindigenous Plants - A Hypothesis. Journal of Ecology 83:887-889.

Blumenthal, D. M., C. Mitchell, P. Pysek, and V. Jarosik. 2009. Synergy between pathogen release and resource availability in plant invasion. Proceedings of the National Academy of Sciences, USA 106:7899-7904.

Bradley, B. A., D. M. Blumenthal, D. S. Wilcove, and L. H. Ziska. 2009. Predicting plant invasions in an era of global change. Trends in Ecology and Evolution 25:310-318.

Breitenbeck, G. A. 2008. Chinese tallow trees a potential bioenergy crop for Louisiana. Available at http://www.lsuagcenter.com/en/communications/publications/agmag/Archive/2008/Sum mer/Chinese+Tallow+Trees+a+Potential+Bioenergy+Crop+for+Louisiana.htm. Louisiana Agriculture Summer 2008.

Buddenhagen, C. E., C. Chimera, and P. Clifford. 2009. Assessing Biofuel Crop Invasiveness: A Case Study. PLoS ONE 4:e5261.

Busch, D. E., and S. D. Smith. 1995. Mechanisms associated with decline of woody species in riparian ecosystems of the southwestern U.S. Ecological Monographs 65:347-370.

Byrne, M., and L. Stone. 2011. The need for 'duty of care' when introducing new crops for sustainable agriculture. Current Opinion in Environmental Sustainability 3:50-54.

California Air Resources Board regulations. 2011 ed. Low Carbon Fuel Standard: Title 17 California Code of Regulations §§ 95480-95490.

Campbell, F. T. 2001. The science of risk assessment for phytosanitary regulation and the impact of changing trade regulations. BioScience 51:148-152.

Carey, J. 1996. The incipient Mediterranean fruit fly population in California: implications for invasion biology. Ecology 77:1690 - 1697.

Carlson, M. L., I. V. Lapina, M. Shephard, J. S. Conn, R. Densmore, P. Spencer, J. Heys, J. Riley, and J. NIelsen. 2008. Invasiveness Ranking System for Non-Native Plants of Alaska. Available at http://www.fs.fed.us/r10/spf/fhp/invasive/invasiveness\%20ranking\%20report.pdf. USDA/USFS.

Carson, H. 1987. Colonization and speciation. Page 187206 in A. Gray, M. Crawley, and P. Edwards, editors. Colonization, Succession and Stability. Blackwell Scientific, Oxford, UK. 
Cerdeira, A. L., and S. O. Duke. 2006. The Current Status and Environmental Impacts of Glyphosate-Resistant Crops: A Review. Journal of Environmental Quality 35:1633-1658.

Chong, K., R. Corlett, D. Yeo, and H. Tan. 2011. Towards a global database of weed risk assessments: a test of transferability for the tropics. Biological Invasions 13:1571-1577.

Christian, C. 2001. Consequences of a biological invasion reveal the importance of mutualism for plant communities. Nature 413:635-639.

Clark, G. F., and E. L. Johnston. 2011. Temporal change in the diversity-invasibility relationship in the presence of a disturbance regime. Ecology Letters 14:52-57.

Colautti, R. I., and H. J. MacIsaac. 2004. A neutral terminology to define 'invasive' species. Diversity and Distributions 10:135-141.

Crawley, M. 1987. What makes a community invasible? Pages 429-453 in A. Gray, M. Crawley, and P. Edwards, editors. Colonization, Succession, and Stability. Blackwell Scientific Publications, Oxford, UK.

Crosti, R., C. Cascone, and S. Cipollaro. 2010. Use of a weed risk assessment for the Mediterranean region of Central Italy to prevent loss of functionality and biodiversity in agro-ecosystems. . Biological Invasions 12:1607-1616.

Crosti, R., C. Cascone, V. Forconi, and S. Cipollaro. 2008. 06. The biofuel weedy menace: weed risk assessment as a management tool to halt loss of farmland biodiversity in Italy. 13th Meeting of the Subsidiary Body on Scientific, Technical and Technological Advice of the Convention on Biological Diversity. Secretariat of the Convention on Biological Diversity, Rome, Italy.

D'Antonio, C. M., and P. M. Vitousek. 1992. Biological invasions by exotic grasses, the grass/fire cycle, and global change. Annual Review Of Ecology And Systematics 23:6387.

Daehler, C. 1998. The taxonomic distribution of invasive angiosperm plants: ecological insights and comparison to agricultural weeds. Biological Conservation 84:167-180.

Daehler, C. C. 2001. Darwin's Naturalization Hypothesis Revisited. The American Naturalist 158:324-330.

Daehler, C. C., and D. A. Carino. 2000. Predicting invasive plants: prospects for a general screening system based on current regional models. Biological Invasions 2:93-102.

Daehler, C. C., J. S. Denslow, S. Ansari, and H.-C. Kuo. 2004. A Risk-Assessment System for Screening Out Invasive Pest Plants from Hawaii and Other Pacific Islands. Conservation Biology 18:360-368.

Daehler, C. C., F. Starr, K. Starr, and J. Leary. 2012. Observational field assessment of invasiveness for candidate biofuels in Hawai' 'i.in USDOE, editor. US DOE Office of Electricity Delivery and Energy Reliability.

Daehler, C. C., and J. G. Virtue. 2010. Likelihood and consequences: reframing the Australian weed risk assessment to reflect a standard model of risk. Plant Protection Quarterly 25:52-55.

Davidson, A. M., M. Jennions, and A. B. Nicotra. 2011. Do invasive species show higher phenotypic plasticity than native species and, if so, is it adaptive? A meta-analysis. Ecology Letters 14:419-431.

Davis, A. S., R. Cousens, J. Hill, R. N. Mack, D. Simberloff, and S. Raghu. 2010. Screening bioenergy feedstock crops to mitigate invasion risk. Frontiers in Ecology and Environment 8:533-539. 
Davis, M., and K. Thompson. 2001. Eight ways to be a colonizer; two ways to be an invader: a proposed nomenclature scheme for invasion ecology. Bulletin of the Ecological Society of America 81:226-230.

Davis, M. A., M. K. Chew, R. J. Hobbs, A. E. Lugo, J. J. Ewel, G. J. Vermeij, J. Brown, H., M. L. Rosenzweig, M. R. Gardener, S. P. Carroll, K. Thompson, S. T. A. Pickett, J. C. Stromberg, P. del Tredici, K. N. Suding, J. G. Eherenfeld, J. P. Grime, J. Mascaro, and J. C. Briggs. 2011a. Don't judge species on their origins. Nature 474:153-154.

Davis, P. B., F. D. Menalled, R. K. D. Peterson, and B. D. Maxwell. 2011b. Refinement of weed risk assessments for biofuels using Camelina sativa as a model species. Journal of Applied Ecology 48.

del Moral, R., and C. H. Muller. 1970. The Allelopathic Effects of Eucalyptus camaldulensis. American Midland Naturalist 83:254-282.

Delaware Department of Agriculture. 2011 ed. Delaware Administrative Code Title 3. .

Diez, J. M., J. J. Sullivan, P. E. Hulme, G. Edwards, and R. P. Duncan. 2008. Darwin’s naturalization conundrum: dissecting taxonomic patterns of species invasions. Ecology Letters 11:674-681.

Duke, S. O., A. C. Blair, F. E. Dayan, R. D. Johnson, K. M. Meepagala, D. Cook, and J. Bajsa. 2009. Is (-)-Catechin a Novel Weapon of Spotted Knapweed (Centaurea stoebe)? Journal Of Chemical Ecology 35:141-153.

Durand, L., and G. Goldstein. 2000. Photosynthesis, photoinhibition, and nitrogen use efficiency in native and invasive tree ferns in Hawaii. Oecologia 126:345-354.

Ellstrand, N., and K. Schierenbeck. 2000. Hybridization as a stimulus for the evolution of invasiveness in plants? Proceedings of the National Academy of Sciences 97:7043-7050.

Elton, C. 1958. The Ecology of Invasions by Animals and Plants. 2nd edition. University of Chicago Press, Chicago, IL.

Environmental Law Institute. 2004. Making a List: Prevention Strategies for Invasive Plants in the Great Lakes States Environmental Law Institute, Washington, DC.

EPA. 2011a. Biofuels and the environment: first triennial report to congress. Available at: http://oaspub.epa.gov/eims/eimscomm.getfile?p_download_id=506091.in O. o. R. a. D. National Center for Environmental Assessment, editor.

EPA. 2011b. Guidance on New Fuel Pathway Approval Process. Available at: http://www.epa.gov/otaq/fuels/renewablefuels/new-pathways/lca-petitioninstructions.htm. U.S. Environmental Protection Agency.

EPA. 2013. Regulation of Fuels and Fuel Additives: Additional Qualifying Renewable Fuel Pathways Under the Renewable Fuel Standard Program; Final Rule Approving Renewable Fuel Pathways for Giant Reed (Arundo donax) and Napier Grass (Pennisetum purpureum). Federal Register 78:41703-41716.

EPA Regulations. 2014. Renewable Fuels Standard: Code of Federal Regulations, Title 40, Part 80, Subpart M. Available at: http://www.ecfr.gov/cgi-bin/textidx? c=ecfr\&tpl=/ecfrbrowse/Title40/40cfr80_main_02.tpl (last visited Feb. 4 2014).

European Commission. 2008. Towards an EU strategy on invasive species (Annex to the Communication to the Council, the European Parliament, the European Economic and Social Committee and the Committee of the Regions). Commission of the European Communities, Commission Staff Working Document. Brussels, Belgium.

Executive Order - Low Carbon Fuel Standard. 2007. Cal. Exec. Order No. S-1-07. 
Executive Order No. 13112. 1999. Invasive Species. Federal Register 64:6183-6186.

FDACS regulations. 2008. Biomass Plantings, Fla. Admin. Code r. 5B-57.011.

Federal Crop Insurance Act. 2011. United States Code Title 7, § 1501-1531 - As amended through P.L. 112-55, effective November 18, 2011.

Federal Highway Administration. 2006. Memorandum - Information: Guidance on 23 U.S.C. $\S 329$ on the Control of Noxious Weeds and Establishment of Native Species, Attachment 1. Available at: http://www.fhwa.dot.gov/hep/noxweeds.htm\#a1.in USDOT, editor.

Federal Seed Act. 2011 ed. United States Code Title 7, §§ 1551-1611.

Firn, J., J. L. Moore, A. S. MacDougall, E. T. Borer, E. W. Seabloom, J. HilleRisLambers, W. S. Harpole, E. E. Cleland, C. S. Brown, J. M. H. Knops, S. M. Prober, D. A. Pyke, K. A. Farrell, J. D. Bakker, L. R. O’Halloran, P. B. Adler, S. L. Collins, C. M. D’Antonio, M. J. Crawley, E. M. Wolkovich, K. J. La Pierre, B. A. Melbourne, Y. Hautier, J. W. Morgan, A. D. B. Leakey, A. Kay, R. McCulley, K. F. Davies, C. J. Stevens, C.-J. Chu, K. D. Holl, J. A. Klein, P. A. Fay, N. Hagenah, K. P. Kirkman, and Y. M. Buckley. 2011. Abundance of introduced species at home predicts abundance away in herbaceous communities. Ecology Letters 14:274-281.

Florida Statutes. 2011 ed. Introduction or release of plant pests, noxious weeds, or organisms affecting plant life; cultivation of nonnative plants; special permit and security required, Florida Stat. ch. 581.083. Division of Plant Industry.

Gassó, N., C. Basnou, and M. Vilà. 2010. Predicting plant invaders in the Mediterranean through a weed risk assessment system. Biological Invasions 12:463-476.

Gerlach, J., John D. 2001. Predicting invaders: comment from Gerlach. Trends In Ecology \& Evolution 16:545.

Gordon, D. 1998. Effects of invasive, non-indigenous plant species on ecosystem processes: lessons from Florida. Ecological Applications 8:975-989.

Gordon, D., and C. Gantz. 2011. Risk assessment for invasiveness differs for aquatic and terrestrial plant species. Biological Invasions 13:1829-1842.

Gordon, D. R., C. A. Gantz, C. L. Jerde, W. L. Chadderton, R. P. Keller, and P. D. Champion. 2012. Weed Risk Assessment for Aquatic Plants: Modification of a New Zealand System for the United States. PLoS ONE 7:e40031.

Gordon, D. R., D. A. Onderdonk, A. M. Fox, and R. K. Stocker. 2008a. Consistent accuracy of the Australian weed risk assessment system across varied geographies. Diversity and Distributions 14:234-242.

Gordon, D. R., D. A. Onderdonk, A. M. Fox, R. K. Stocker, and C. A. Gantz. 2008b. Predicting Invasive Plants in Florida Using the Australian Weed Risk Assessment. Invasive Plant Science and Management. Invasive Plant Science and Management 2008:2.

Gordon, D. R., K. J. Tancig, D. A. Onderdonk, and C. A. Gantz. 2011. Assessing the invasive potential of biofuel species proposed for Florida and the United States using the Australian Weed Risk Assessment. Biomass and Bioenergy 35:74-79.

Gordon et al. ongoing. Weed Risk Assessments for Florida based on the Australia/New Zealand Weed Risk Assessment model. Available at: http://www.hear.org/wra/tncflwra/. The Nature Conservancy. The Nature Conservancy.

Gray, A. 1986. Do invading species have definable genetic characteristics? Philosophical Transactions of the Royal Society of London B 314:655-674. 
Gressel, J. 2005. Introduction - the challenges of ferality.in J. Gressel, editor. Crop Ferality and Volunteerism. Taylor \& Francis Group, Boca Raton, FL.

Grotkopp, E., M. Rejmánek, and T. Rost. 2002. Toward a causal explanation of plant invasiveness: seedling growth and life-history strategies of 29 pine (Pinus) species. The American Naturalist 159:396-419.

Hails, R., and T. Timms-Wilson. 2007. Genetically modified organisms as invasive species?in W. Nentwig, editor. Biological Invasions. Springer-Verlag, Heidelberg, Germany.

Hawkes, C. V. 2007. Are invaders moving targets? The generality and persistence of advantages in size, reproduction, and enemy release in invasive plant species with time since introduction. American Naturalist 170:832-843.

HPWRA. 2010. Hawaii-Pacific Weed Risk Assessment (HPWRA) system; www.hpwra.org/.

Indiana Dept. of Natural Resources. 2011. Species assessments. Available at: www.in.gov/dnr/4619.htm. Indiana Dept. of Natural Resources.

IPCC. 1997. International Plant Protection Convention, new revised text. Available at: https://www.ippc.int/file_uploaded//publications/13742.New_Revised_Text_of_the_Inter national_Plant_Protectio.pdf. FAO: Rome, Italy.

ISAC. 2006. Invasive species definition clarification and guidance white paper. NISC, Washington, DC.

ISAC. 2009. Biofuels: Cultivating Energy, not Invasive Species. NISC, Washington, DC.

IUCN. 2009. Guidelines on biofuels and invasive species. Available at: http://www.iucn.org/about/union/secretariat/offices/iucnmed/iucn_med_programme/speci es/invasive_species/. IUCN, Gland, Switzerland.

IUCN. 2011. Invasive Species Website: http://www.iucn.org/about/union/secretariat/offices/iucnmed/iucn_med_programme/speci es/invasive_species/. IUCN.

Jakubowski, A. R., M. D. Casler, and R. D. Jackson. 2011. Has Selection for Improved Agronomic Traits Made Reed Canarygrass Invasive? PLoS ONE 6:e25757.

Keane, R., and M. Crawley. 2002. Exotic plant invasions and the enemy release hypothesis. Trends In Ecology \& Evolution 17:164-170.

Keller, R. P., D. M. Lodge, and D. C. Finnoff. 2006. Risk assessment for invasive species produces net bioeconomic benefits. Proceedings of the National Academy of Sciences 104:203-207.

Keller, R. P., and C. Perrings. 2011. International Policy Options for Reducing the Environmental Impacts of Invasive Species. BioScience 61:1005-1012.

Kennedy, T. A., S. Naeem, K. M. Howe, J. M. H. Knops, D. Tilman, and P. Reich. 2002. Biodiversity as a barrier to ecological invasion. Nature 417:636-638.

Kolar, C. S., and D. M. Lodge. 2001. Progress in invasion biology: predicting invaders. Trends In Ecology \& Evolution 16:199-204.

Koop, A., L. Fowler, L. Newton, and B. Caton. 2012. Development and validation of a weed screening tool for the United States. Biological Invasions 14:273-294.

Kowarik, I. 1995. Time lags in biological invasions with regard to the success and failure of alien species. Pages 15-38 in P. Pysek, K. Prach, M. Rejmanek, and M. Wade, editors. Plant Invasions - General Aspects and Special Problems. SPB Academic Publishing, Amsterdam, the Netherlands. 
Lavergne, S., and J. Molofsky. 2007. Increased genetic variation and evolutionary potential drive the success of an invasive grass. Proceedings of the National Academy of Sciences 104:3883-3888.

Leishman, M. R., T. Haslehurst, A. Ares, and Z. Baruch. 2007. Leaf trait relationships of native and invasive plants: community- and global-scale comparisons. New Phytologist 176:635-643.

Levine, J. M. 2000. Species diversity and biological invasions: relating local process to community pattern. Science 288:852-854.

Levine, J. M., M. Vila, C. M. D'Antonio, J. S. Dukes, K. Grigulis, and S. Lavorel. 2003. Mechanisms underlying the impacts of exotic plant invasions. Proceedings Of The Royal Society Of London Series B-Biological Sciences 270:775-781.

Lewontin, R. 1965. Selection for Colonizing Ability. Pages 77-94 in The First International Union of Biological Sciences Symposia on General Biology. Academic Press, Asilomar, CA.

Lockwood, J. L., D. Simberloff, M. L. McKinney, and B. von Holle. 2001. How many, and which, plants will invade natural areas? Biological Invasions 3:1-8.

Lonsdale, W. 1999. Global patterns of plant invasions and the concept of invasibility. Ecology 80:1522-1536.

Lonsdale, W. M., and F. Fitzgibbon. 2011. The known unknowns - managing the invasion risk from biofuels. Current Opinion in Environmental Sustainability 3:31-35.

Louisiana statutes. 2011 ed. La. Rev. Stat. Title 3.

Low, T., C. Booth, and A. Sheppard. 2011. Weedy biofuels: what can be done? Current Opinion in Environmental Sustainability 3:55-59.

Lowe, S., M. Browne, S. Boudjelas, and M. De Poorter. 2000. 100 of the World's Worst Invasive Alien Species: A selection from the Global Invasive Species database. Available at http://issg.org/database/species/reference_files/100English.pdf. Invasive Species Specialist Group, Species Survival Commission, World Conservation Union (IUCN).

Ludsin, S., and A. Wolfe. 2001. Biological invasion theory: Darwin's contributions from The Origin of Species. BioScience 51:780-789.

Lyons, K. G., and M. W. Schwartz. 2001. Rare species loss alters ecosystem function - invasion resistance. Ecology Letters 4:358-365.

Mack, M. C., and C. M. D'Antonio. 2003. Exotic grasses alter controls over soil nitrogen dynamics in a Hawaiian woodland. Ecological Applications 13:154-166.

Mack, R., D. Simberloff, W. Lonsdale, H. Evans, M. Clout, and F. Bazzaz. 2000. Biotic invasions: causes, epidemiology, global consequences, and control. Issues in Ecology 5:2-20.

Maron, J. L., M. Vilá, R. Bommarco, S. Elmendorf, and P. Beardsley. 2004. Rapid evolution of an invasive plant. Ecological Monographs 74:261-280.

May, F., and J. Ash. 1990. An Assessment of the Allelopathic Potential of Eucalyptus. Australian Journal of Botany 38:245-254.

McClay, A., A. Sissons, C. Wilson, and S. Davis. 2010. Evaluation of the Australian weed risk assessment system for the prediction of plant invasiveness in Canada. Biological Invasions 12:4085-4098.

McDowell, S., and D. Turner. 2002. Reproductive effort in invasive and non-invasive Rubus. Oecologia 133:102-111. 
Minnesota Board of Water and Soil Resources. 2008. Reinvest in Minnesota - Clean Energy Program Guidelines and Standards. Available at (2008). http://www.bwsr.state.mn.us/RIM-CE/2008_RIM-CE_Report.pdf.

Mitchell, C., and A. Power. 2003. Release of invasive plants from fungal and viral pathogens. Nature 421:625-627.

Mohamed, K. I., M. Papes, R. Williams, B. W. Benz, and A. T. Peterson. 2006. Global invasive potential of 10 parasitic witchweeds and related Orobanchaceae. Ambio 35:281-288.

Moles, A. T., M. A. M. Gruber, and S. P. Bonser. 2008. A new framework for predicting invasive plant species. Journal of Ecology 96:13-17.

Montana Department of Agriculture. 2010. Montana Noxious Weed List. Effective: September 2010. Available at:http://agr.mt.gov/agr/Programs/Weeds/PDF/weedList2010.pdf.

Moyle, P. B., and M. P. Marchetti. 2006. Predicting invasion success: Freshwater fishes in California as a model. BioScience 56:515-524.

Nagel, J., and K. Griffin. 2001. Construction cost and invasive potential: comparing Lythrum salicaria (Lythraceae) with co-occurring native species along pond banks. American Journal Of Botany 88:2252-2258.

NISC. 2003. General guidelines for the establishment and evaluation of invasive species early detection and rapid response systems. Version 1.in NISC, editor., Washington, DC.

NISC. 2008. 2008-2012 National Invasive Species Management Plan.35 pp.

Nishida, T., N. Yamashita, M. Asai, S. Kurokawa, T. Enomoto, P. C. Pheloung, and R. H. Groves. 2008. Developing a pre-entry weed risk assessment system for use in Japan. . Biological Invasions 11:1319-1333.

Nuzzo, V. 1993. Distribution and spread of the invasive biennial Alliaria petiolata (garlic mustard) in North America. Pages 137-145 in B. McKnight, editor. Biological Pollution: the control and impact of invasive exotic species. Indiana Academy of Science, Indianapolis, IN.

Office of Science and Technology Policy. 1986. Coordinated Framework for Regulation of Biotechnology. Federal Register 51:23302-23393.

Oregon Legislative Assembly. 2007. Oregon Laws Ch. 729, H.B. 2210: An act relating to financial administration of the State Parks and Recreation Department; limiting expenditures; and declaring an emergency.

Palacio-López, K., and E. Gianoli. 2011. Invasive plants do not display greater phenotypic plasticity than their native or non-invasive counterparts: a meta-analysis. Oikos 120:1393-1401.

Pandit, M. K., M. J. O. Pocock, and W. E. Kunin. 2011. Ploidy influences rarity and invasiveness in plants. Journal of Ecology:no-no.

Parker, C., B. P. Caton, and L. Fowler. 2007. Ranking Nonindigenous Weed Species by Their Potential to Invade the United States. Weed Science 55:386-397.

Pattison, R., G. Goldstein, and A. Ares. 1998. Growth, biomass allocation and photosynthesis of invasive and native Hawaiian rainforest species. Oecologia 117:449-459.

Pheloung, P. C. 1999. Form A - Interpreting the questions in the Weed Risk Assessment system, available at http://www.daff.gov.au/_data/assets/pdf_file/0009/859851/form-ainterpreting-qs-wra-system.pdf. 
Pheloung, P. C., P. A. Williams, and S. R. Halloy. 1999. A weed risk assessment model for use as a biosecurity tool evaluating plant introductions. Journal of Environmental Management 57:239-251.

Plant Epidemiology and Risk Analysis Laboratory. 2012. Background information on the PPQ weed risk assessment process and products.in P. P. a. Q. Center for Plant Health Science and Technology, editor. USDA, Raleigh, NC.

Plant Protection Act. 2011 ed. United States Code Title 7, § 7701-7786.

Prati, D., and O. Bossdorf. 2004. Allelopathic inhibition of germination by Alliaria petiolata (Brassicaceae). American Journal Of Botany 91:285-288.

Pyšek, P., D. M. Richardson, M. Rejmanek, G. L. Webster, M. Williamson, and I. Kirschner. 2004. Alien plants in checklists and floras: towards better communication between taxonomists and ecologists. Taxon 53:131-143.

Quinn, L., J. Stewart, T. Yamada, Y. Toma, M. Saito, K. Shimoda, and F. Fernández. 2012. Environmental Tolerances of Miscanthus sinensis in Invasive and Native Populations. Bioenergy Research 5:139-148.

Quinn, L. D., J. N. Barney, J. S. N. McCubbins, and A. B. Endres. 2013. Navigating the "Noxious" and "Invasive” Regulatory Landscape: Suggestions for Improved Regulation. BioScience 63:124-131.

Quinn, L. D., D. P. Matlaga, J. R. Stewart, and A. S. Davis. 2011. Empirical Evidence of LongDistance Dispersal in Miscanthus sinensis and Miscanthus $\times$ giganteus. Invasive Plant Science and Management 4:142-150.

Radford, I., and R. Cousens. 2000. Invasiveness and comparative life-history traits of exotic and indigenous Senecio species in Australia. Oecologia 125:531-542.

Raghu, S., R. C. Anderson, C. C. Daehler, A. S. Davis, R. N. Wiedenmann, D. Simberloff, and R. N. Mack. 2006. Adding Biofuels to the Invasive Species Fire? Science 313:1742.

Reinvest in Minnesota Clean Energy Program. 2011. Minn. Stat. § 103F.518.

Rejmanek, M. 2011. Invasiveness. Pages 379-385 in D. Simberloff and M. Rejmanek, editors. Encyclopedia of biological invasions. University of California Press, Berkeley, CA.

Rejmánek, M. 1996. A theory of seed plant invasiveness: the first sketch. Biological Conservation 78:171-181.

Rejmánek, M. 2000. Invasive plants: approaches and predictions. Austral Ecology 25:497-506.

Rejmanek, M., and M. Pitcairn. 2002. When is eradication of exotic pests a realistic goal? Pages 249-253 in C. Veitch and M. Clout, editors. Turning the tide: the eradication of invasive species - Proceedings of the International Conference on Eradication of Island Invasives. IUCN, Switzerland.

Rejmánek, M., and D. Richardson. 1996. What attributes make some plant species more invasive? Ecology 77:1655-1661.

RGGI. 2005. Memorandum of Understanding (Dec. 20, 2005). Available at http://www.rggi.org/docs/mou_12_20_05.pdf.

RGGI. 2008. Rev. Model Rule § XX-10.5(c)(ii) (2008).

Richardson, D. M., and R. Blanchard. 2011. Learning from our mistakes: minimizing problems with invasive biofuel plants. Current Opinion in Environmental Sustainability 3:36-42.

Richardson, D. M., P. Pyšek, M. Rejmánek, M. G. Barbour, F. D. Panetta, and C. J. West. 2000. Naturalization and invasion of alien plants: concepts and definitions. Diversity and Distributions 6:93-107. 
Ross, M. 2011. New miscanthus development possible biomass game-changer? FarmWeek. Illinois Farm Bureau, Bloomfield, IL.

Roundtable for Sustainable Biofuels. 2010. RSB Principles \& Criteria for Sustainable Biofuel Production (RSB-STD-01-001, Version 2.0). Available at: http://rsb.epfl.ch/page-24929en.html. Round Table For Sustainable Biofuels, Lausanne, Switzerland.

Sakai, A., F. Allendorf, J. Holt, D. Lodge, J. Molofsky, K. With, S. Baughman, R. Cabin, J. Cohen, N. Ellstrand, D. McCauley, P. O'Neil, I. Parker, J. Thompson, and S. Weller. 2001. The population biology of invasive species. Annual Review Of Ecology And Systematics 32:305-332.

Scheiner, S., and J. Teeri. 1986. Phenotypic flexibility and genetic adaptation along a gradient of secondary forest succession in the grass Danthonia spicata. Canadian Journal of Botany 64:739-747.

Schierenbeck, K., R. Mack, and R. Sharitz. 1994. Effects of herbivory on growth and biomass allocation in native and introduced species of Lonicera. Ecology 75:1661-1672.

Schrader, G., and J.-G. Unger. 2003. Plant quarantine as a measure against invasive alien species: the framework of the International Plant Protection Convention and the plant health regulations in the European Union. Biological Invasions 5:357-364.

Shea, K., and P. Chesson. 2002. Community ecology theory as a framework for biological invasions. Trends In Ecology \& Evolution 17:170-176.

Simberloff, D. 2010. Invasive species.in N. S. Sodhi and P. R. Ehrlich, editors. Conservation Biology for All. Oxford University Press, Oxford, UK.

Simberloff, D. 2011. Non-natives: 141 scientists object. Nature 475:36.

Smith, M., and A. Knapp. 2001. Physiological and morphological traits of exotic, invasive exotic, and native plant species in tallgrass prairie. International Journal of Plant Science 162:785-792.

Steiner, J., K. Lewis, H. Baumes, and N. Brown. 2012. A Feedstock Readiness Level Tool to Complement the Aviation Industry Fuel Readiness Level Tool. Bioenergy Research:1-12.

Stinson, K. A., S. A. Campbell, J. R. Powell, B. E. Wolfe, R. M. Callaway, G. C. Thelen, S. G. Hallett, D. Prati, and J. N. Klironomos. 2006. Invasive Plant Suppresses the Growth of Native Tree Seedlings by Disrupting Belowground Mutualisms. PLoS Biology 4.

Stohlgren, T., P. Pyšek, J. Kartesz, M. Nishino, A. Pauchard, M. Winter, J. Pino, D. Richardson, J. Wilson, B. Murray, M. Phillips, L. Ming-yang, L. Celesti-Grapow, and X. Font. 2011. Widespread plant species: natives versus aliens in our changing world. Biological Invasions:1-14.

Stohlgren, T. J., and J. L. Schnase. 2006. Risk Analysis for Biological Hazards: What We Need to Know about Invasive Species. Risk Analysis 26:163-173.

te Beest, M., J. J. Le Roux, D. M. Richardson, A. K. Brysting, J. Suda, M. Kubešová, and P. Pyšek. 2011. The more the better? The role of polyploidy in facilitating plant invasions. Annals of Botany.

Thelen, G. C., J. M. Vivanco, B. Newingham, W. Good, H. P. Bais, P. Landres, A. Caesar, and R. M. Callaway. 2005. Insect herbivory stimulates allelopathic exudation by an invasive plant and the suppression of natives. Ecology Letters 8:209-217.

Torchin, M., K. Lafferty, A. Dobson, V. McKenzie, and A. Kurls. 2003. Introduced species and their missing parasites. Nature 421:628-630. 
Torchin, M. E., and C. E. Mitchell. 2004. Parasites, pathogens, and invasions by plants and animals. Frontiers In Ecology And The Environment 2:183-190.

U.S. Code. 2014 ed.-a. Biomass Crop Assistance Program: United States Code Title 7, § 8111.

U.S. Code. 2014 ed.-b. Credit for alcohol fuel, biodiesel and alternative fuel mixtures: United States Code Title 26, § 6426.

USDA. 2010. State Noxious-Weed Seed Requirements Recognized in the Administration of the Federal Seed Act. Available at: http://www.ams.usda.gov/AMSv1.0/getfile?dDocName=STELPRD3317318.

USDA. 2011a. BCAP Project Areas Listing. Available at: http://www.fsa.usda.gov/FSA/webapp?area=home\&subject=ener\&topic=bcap-pjt-bloc. USDA Farm Services Agency.

USDA. 2011b. USDA announces new insurance pilot program for biofuel-friendly oilseedcrop with potential to create jobs, stimulate rural economies. Available at: http://www.usda.gov/wps/portal/usda/usdahome?contentid=2011/11/0498.xml. USDA News Release No. 0498.11.

USDA Farm Service Agency. 2010. Programmatic Environmental Impact Statement: Biomass Crop Assistance Program. USDA Farm Service Agency.

USDA Farm Service Agency. 2011. Environmental Assessment: Proposed BCAP Giant Miscanthus (Miscanthus X giganteus) Establishment and Production in Arkansas, Missouri, Ohio, and Pennsylvania. Biomass Crop Assistance Program. Sponsored by Aloterra Energy LLC and MFA Oil Biomass LLC.

USDA Farm Service Agency. 2012. Mitigated Finding of No Significant Impact: Environmental Assessment Proposed BCAP Giant Miscanthus (Miscanthus X giganteus) Establishment and Production in Georgia, North Carolina, and South Carolina. USDA Farm Service Agency Biomass Crop Assistance Program.

USDA Regulations. 2011 ed.-a. BCAP: Code of Federal Regulations Title 7, Pt. 1450.

USDA regulations. 2011 ed.-b. Code of Federal Regulations Title 7, Pt. 340: Introduction of Organisms and Products Altered or Produced Through Genetic Engineering which are Plant Pests or which There is Reason to Believe are Plant Pests.

USDA Regulations. 2011 ed.-c. Foreign Quarantine Notices: Code of Federal Regulations Title 7, Pt. 319.

USDA Regulations. 2011 ed.-d. Noxious Weed Regulations: Code of Federal Regulations Title 7, Pt. 360.

USDA/RMA. 2012. Federal Crop Insurance Corp Summary of Business Report for 2009 through 2012, as of 6-18-2012. Available at: http://www3.rma.usda.gov/apps/sob/current_week/sobrpt2009-2012.pdf.

Van Kleunen, M., E. Weber, and M. Fischer. 2010. A meta-analysis of trait differences between invasive and non-invasive plant species. Ecology Letters 13:235-245.

van Ruijven, J., G. de Deyn, and F. Berendse. 2003. Diversity reduces invasibility in experimental plant communities: the role of plant species. Ecology Letters 6:910-918.

Vitousek, P. 1986. Biological invasions and ecosystem properties: can species make a difference? Pages 163-176 in H. Mooney and J. Drake, editors. Ecology of Biological Invasions of North America and Hawai'i. Springer-Verlag, New York, NY.

Vitousek, P., L. Walker, L. Whiteaker, D. Mueller-Dombois, and P. Matson. 1987. Biological invasion by Myrica faya alters ecosystem development in Hawai'i. Science 238:802-804. 
Warwick, S. I., and C. N. Stewart Jr. 2005. Crops come from wild plants - how domestication, transgenes, and linkage together shape ferality. Pages 9-30 in J. Gressel, editor. Crop Ferality and Volunteerism. Taylor \& Francis Group, Boca Raton, FL.

Weir, T. L., H. P. Bais, and J. M. Vivanco. 2003. Intraspecific and interspecific interactions mediated by a phytotoxin, (-)-catechin, secreted by the roots of Centaurea maculosa (spotted knapweed). Journal Of Chemical Ecology 29:2397-2412.

White, I. R., and D. Backhouse. 2007. Comparison of fungal endophyte communities in the invasive panicoid grass Hyparrhenia hirta and the native grass Bothriochloa macra. Australian Journal Of Botany 55:178-185.

Williams, D., and R. Black. 1993. Phenotypic variation in contrasting temperature environments: growth and photosynthesis in Pennisetum setaceum from different altitudes on Hawai'i. Functional Ecology 7:623-633.

Williams, D., R. Mack, and R. Black. 1995. Ecophysiology of introduced Pennisetum setaceum on Hawaii: the role of phenotypic plasticity. Ecology 76:1569-1580.

Williamson, M., and A. Fitter. 1996a. The characters of successful invaders. Biological Conservation 78:163-170.

Williamson, M., and A. Fitter. 1996b. The varying success of invaders. Ecology 77:1661-1666.

Wolfe, L. 2002. Why alien invaders succeed: support for the escape-from-enemy hypothesis. American Naturalist 160:705-711.

WTO. 1994. World Trade Organization Agreement on the Application of Sanitary and Phytosanitary Measures. Marrakesh Agreement Establishing the World Trade Organization.

Xie, G., and L. Peng. 2011. Genetic Engineering of Energy Crops: A Strategy for Biofuel Production in ChinaFree Access. Journal of Integrative Plant Biology 53:143-150.

Yamashita, N., A. Ishida, H. Kushima, and N. Tanaka. 2000. Acclimation to sudden increase in light favoring an invasive over native trees in subtropical islands, Japan. Oecologia 125:412-419.

Zou, J., W. E. Rogers, and E. Siemann. 2007. Differences in morphological and physiological traits between native and invasive populations of Sapium sebiferum. Functional Ecology 21:721-730. 
Table 1: Identified predictors of invasiveness in introduced species, their incorporation in four Weed Risk Assessment models, and whether the characteristic is sought in new biofuel feedstock crops.

\begin{tabular}{|c|c|c|c|c|c|c|c|}
\hline Predictor & & References & 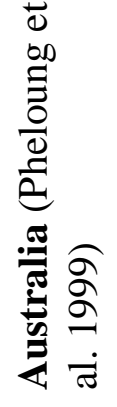 & 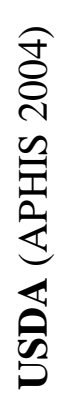 & 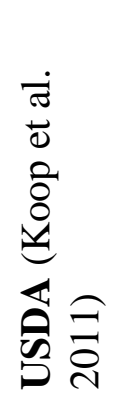 & 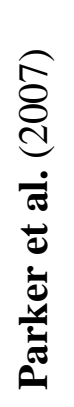 & 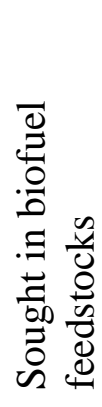 \\
\hline Reproducti & $\begin{array}{l}\text { Traits } \\
\text { High/generalized propagule } \\
\text { dispersal }\end{array}$ & (Rejmánek 1996, 2000) & $X$ & $X$ & $\mathrm{X}$ & $\mathrm{X}$ & \\
\hline & High propagule production & $\begin{array}{l}\text { (Williamson and Fitter 1996a, Kolar } \\
\text { and Lodge 2001, Moyle and Marchetti } \\
\text { 2006) }\end{array}$ & $\mathrm{X}$ & $\mathrm{X}$ & $X$ & $\mathrm{X}$ & $\mathrm{X}$ \\
\hline & Vegetative reproduction / spread & $\begin{array}{l}\text { (Rejmánek 1996, 2000, Kolar and } \\
\text { Lodge 2001) (Daehler 1998) }\end{array}$ & $X$ & $X$ & & $\mathrm{X}$ & \\
\hline & Dormancy/seed bank formation & (Rejmánek 2000) & $\mathrm{X}$ & $\mathrm{X}$ & $X$ & $\mathrm{X}$ & \\
\hline & Short generation times & $\begin{array}{l}\text { (Rejmánek 1996, Rejmánek and } \\
\text { Richardson 1996, Rejmánek 2000) }\end{array}$ & $\mathrm{X}$ & $X$ & $X$ & & $X$ \\
\hline & Self-compatible & & $\mathrm{X}$ & & $\mathrm{X}$ & & \\
\hline & Hybridization & $\begin{array}{l}\text { (Ellstrand and Schierenbeck 2000, } \\
\text { Mack et al. 2000) }\end{array}$ & $X$ & & & & \\
\hline & Seed size & $\begin{array}{l}\text { (Rejmánek 1996, Rejmánek and } \\
\text { Richardson 1996, Gerlach } 2001 \text { and } \\
\text { refs., Grotkopp et al. 2002, Stohlgren } \\
\text { et al. 2011) }\end{array}$ & & & & $X$ & \\
\hline
\end{tabular}




\begin{tabular}{|c|c|c|c|c|c|c|}
\hline \multicolumn{7}{|l|}{ Distribution and Historical Factors } \\
\hline $\begin{array}{l}\text { Weedy/invasive behavior } \\
\text { (agricultural or natural settings, } \\
\text { locally or elsewhere) }\end{array}$ & $\begin{array}{l}\text { (Kolar and Lodge 2001, Lockwood et } \\
\text { al. 2001, Moyle and Marchetti 2006) }\end{array}$ & $\mathrm{X}$ & $\mathrm{X}$ & $\mathrm{X}$ & $X$ & \\
\hline $\begin{array}{l}\text { Congener invasive (locally or } \\
\text { elsewhere) }\end{array}$ & & $\mathrm{X}$ & $\mathrm{X}$ & $\mathrm{X}$ & & \\
\hline Weedy relatives & (Daehler 1998) & $\mathrm{X}$ & $\mathrm{X}$ & $\mathrm{X}$ & & \\
\hline Domestication history & (Williamson and Fitter 1996a) & $\mathrm{X}$ & & $\mathrm{X}$ & $X$ & \\
\hline $\begin{array}{l}\text { Naturalized (locally or } \\
\text { elsewhere) }\end{array}$ & $\begin{array}{l}\text { (Kolar and Lodge 2001, Moyle and } \\
\text { Marchetti 2006) }\end{array}$ & $\mathrm{X}$ & & $X$ & & \\
\hline $\begin{array}{l}\text { Abundance/dominance in home } \\
\text { range }\end{array}$ & $\begin{array}{l}\text { (Crawley 1987, Williamson and Fitter } \\
\text { 1996a, Firn et al. 2011) }\end{array}$ & & $\mathrm{X}$ & & & \\
\hline Novel taxon in new range & $\begin{array}{l}\text { (Rejmánek 1996, Williamson and } \\
\text { Fitter 1996a, Lockwood et al. 2001) }\end{array}$ & & & & & \\
\hline \multicolumn{7}{|l|}{ Environmental Tolerance } \\
\hline $\begin{array}{ll}\text { Tolerates marginal lands / low } \\
\text { resource availability }\end{array}$ & $\begin{array}{l}\text { (Pattison et al. 1998, Shea and } \\
\text { Chesson 2002) }\end{array}$ & $\mathrm{X}$ & $\mathrm{X}$ & & $\mathrm{X}$ & $\mathrm{X}$ \\
\hline Preadapted to climate / habitats & $\begin{array}{l}\text { (Rejmánek 1996, Moyle and Marchetti } \\
\text { 2006) }\end{array}$ & $\mathrm{X}$ & $\mathrm{X}$ & $\mathrm{X}$ & $\mathrm{X}$ & $\mathrm{X}$ \\
\hline Broad environmental tolerance & $\begin{array}{l}\text { (Williams and Black 1993, Williams } \\
\text { et al. 1995, Durand and Goldstein } \\
\text { 2000, Yamashita et al. 2000, Moyle } \\
\text { and Marchetti 2006) }\end{array}$ & $\mathrm{X}$ & $\mathrm{X}$ & $\mathrm{X}$ & $\mathrm{X}$ & $\mathrm{X}$ \\
\hline Tolerates disturbance & $\begin{array}{l}\text { (Mack et al. 2000, Radford and } \\
\text { Cousens 2000, Rejmánek 2000, Van } \\
\text { Kleunen et al. 2010) }\end{array}$ & $\mathrm{X}$ & $\mathrm{X}$ & $\mathrm{X}$ & & $\mathrm{X}$ \\
\hline Aquatic & & $\mathrm{X}$ & $\mathrm{X}$ & $\mathrm{X}$ & & \\
\hline $\begin{array}{l}\text { Takes advantage of resource } \\
\text { pulses/changes / climate change }\end{array}$ & $\begin{array}{l}\text { (Yamashita et al. 2000, Shea and } \\
\text { Chesson 2002, Bradley et al. 2009) }\end{array}$ & & & & $\mathrm{X}$ & \\
\hline Phenotypic plasticity & $\begin{array}{l}\text { (Lewontin 1965, Bazzaz 1986, Gray } \\
\text { 1986, Scheiner and Teeri 1986, }\end{array}$ & & & & & \\
\hline
\end{tabular}




\begin{tabular}{|c|c|c|c|c|c|c|}
\hline & $\begin{array}{l}\text { Williams et al. 1995, Rejmánek 1996, } \\
\text { 2000, Yamashita et al. 2000, Lavergne } \\
\text { and Molofsky 2007) }\end{array}$ & & & & & \\
\hline $\begin{array}{l}\text { Low construction cost tissues } \\
\text { (e.g., high SLA) }\end{array}$ & $\begin{array}{l}\text { (Williams and Black 1993, } \\
\text { Williamson and Fitter 1996a, Pattison } \\
\text { et al. 1998, Baruch and Goldstein } \\
\text { 1999, Durand and Goldstein 2000, } \\
\text { Nagel and Griffin 2001, Smith and } \\
\text { Knapp 2001, Grotkopp et al. 2002, } \\
\text { McDowell and Turner 2002, Maron et } \\
\text { al. 2004, Leishman et al. 2007) (but } \\
\text { see Durand and Goldstein 2000) }\end{array}$ & & & & & \\
\hline \multicolumn{7}{|l|}{ Growth Habit } \\
\hline Storage tissues underground & & $\mathrm{X}$ & $\mathrm{X}$ & & & $\mathrm{X}$ \\
\hline $\begin{array}{l}\text { Climbing/smothering growth } \\
\text { habit }\end{array}$ & (Daehler 1998) & $\mathrm{X}$ & & $\mathrm{X}$ & $\mathrm{X}$ & \\
\hline $\begin{array}{l}\text { Novel community structure } \\
\text { component }\end{array}$ & & & $\mathrm{X}$ & $\mathrm{X}$ & $\mathrm{X}$ & \\
\hline \multicolumn{7}{|l|}{ Competition / Defense } \\
\hline Rapid growth rate & $\begin{array}{l}\text { (Grotkopp et al. 2002, Shea and } \\
\text { Chesson 2002, Van Kleunen et al. } \\
\text { 2010) }\end{array}$ & $\mathrm{X}$ & $\mathrm{X}$ & & & $\mathrm{X}$ \\
\hline Highly competitive for resources & $\begin{array}{l}\text { (D'Antonio and Vitousek 1992, Mack } \\
\text { et al. 2000, Levine et al. 2003) }\end{array}$ & implied & & & $\mathrm{X}$ & $\mathrm{X}$ \\
\hline Forms dense stands & (Crawley 1987) & $\mathrm{X}$ & & $\mathrm{X}$ & & \\
\hline \multicolumn{7}{|l|}{ Biotic Interactions } \\
\hline Escape from herbivores & $\begin{array}{l}\text { (Elton 1958, Schierenbeck et al. 1994, } \\
\text { Blossey and Notzold 1995, Baruch } \\
\text { and Goldstein 1999, Keane and } \\
\text { Crawley 2002, Wolfe 2002, Hawkes } \\
\text { 2007) }\end{array}$ & $\mathrm{X}$ & $\mathrm{X}$ & & $\mathrm{X}$ & $\mathrm{X}$ \\
\hline
\end{tabular}




\begin{tabular}{|c|c|c|c|c|c|c|}
\hline Escape from parasites & $\begin{array}{l}\text { (Torchin et al. 2003, Torchin and } \\
\text { Mitchell 2004) }\end{array}$ & $\mathrm{X}$ & $\mathrm{X}$ & & & $\mathrm{X}$ \\
\hline Escape from pathogens & $\begin{array}{l}\text { (Mitchell and Power 2003, Hawkes } \\
\text { 2007, Blumenthal et al. 2009) }\end{array}$ & $X$ & $\mathrm{X}$ & & & $\mathrm{X}$ \\
\hline Allelopathy & $\begin{array}{l}\text { (Bais et al. 2003, Weir et al. 2003, } \\
\text { Thelen et al. 2005, Abhilasha et al. } \\
\text { 2008) (but see also Prati and Bossdorf } \\
\text { 2004, Blair et al. 2006, Duke et al. } \\
\text { 2009) }\end{array}$ & $X$ & $\mathrm{X}$ & $\mathrm{X}$ & & \\
\hline Parasitic & (Mohamed et al. 2006) & $\mathrm{X}$ & $\mathrm{X}$ & $\mathrm{X}$ & & \\
\hline Host (vector) for pests/pathogens & & $\mathrm{X}$ & & implied & $\mathrm{X}$ & \\
\hline $\begin{array}{l}\text { Disruption of ecosystem } \\
\text { resource availability }\end{array}$ & $\begin{array}{l}\text { (Busch and Smith 1995, Gordon 1998, } \\
\text { Mack and D'Antonio 2003) }\end{array}$ & & $\mathrm{X}$ & & $\mathrm{X}$ & \\
\hline Independence from mutualists & $\begin{array}{l}\text { (Daehler 1998, Rejmánek 2000, } \\
\text { Stinson et al. 2006) (but see also } \\
\text { Vitousek et al. 1987, White and } \\
\text { Backhouse 2007) }\end{array}$ & $X$ & & $\mathrm{X}$ & & $\mathrm{X}$ \\
\hline Disruption of local mutualism & (Christian 2001, Stinson et al. 2006) & & & & $\mathrm{X}$ & \\
\hline Phylogenetic Factors & $\begin{array}{l}\text { (Rejmánek and Richardson 1996, } \\
\text { Daehler 1998, Kolar and Lodge 2001, } \\
\text { Lockwood et al. 2001) }\end{array}$ & & & & & \\
\hline Poaceae (grasses) & (Daehler 1998, Lockwood et al. 2001) & $\mathrm{X}$ & & $\mathrm{X}$ & $\mathrm{X}$ & $\mathrm{X}$ \\
\hline Fabaceae (legumes) & (Daehler 1998) & $\mathrm{X}$ & & $\mathrm{X}$ & $\mathrm{X}$ & \\
\hline Related to GE crop & & & & & $\mathrm{X}$ & \\
\hline \multicolumn{7}{|l|}{ Other Concerns } \\
\hline Toxic/allergenic to humans & & $\mathrm{X}$ & $\mathrm{X}$ & & $\mathrm{X}$ & \\
\hline Toxic to local herbivores & & $\mathrm{X}$ & & $\mathrm{X}$ & $\mathrm{X}$ & \\
\hline Increases fire risk & $\begin{array}{l}\text { (reviewed in D'Antonio and Vitousek } \\
\text { 1992) }\end{array}$ & $X$ & & $X$ & $X$ & \\
\hline Thorns/spines/burrs & & $X$ & & & $\mathrm{X}$ & \\
\hline
\end{tabular}




\begin{tabular}{|cl|}
\hline Genetic Factors & \\
\hline \multirow{2}{*}{ High genetic variability } & (Bazzaz 1986, Gray 1986, Rejmánek \\
& 1996, Lavergne and Molofsky 2007) \\
\hline & (Bazzaz 1986, Badyaev and Hill 2000, \\
& Badyaev et al. 2000, Mack et al. 2000, \\
Rapid evolutionary change & Sakai et al. 2001, Maron et al. 2004, \\
& Lavergne and Molofsky 2007) \\
\hline Ploidy level & (Pandit et al. 2011) \\
\hline
\end{tabular}


Table 2: Summary of IUCN recommended biofuel feedstock selection and cultivation best practices (IUCN 2009).

\begin{tabular}{|c|c|}
\hline Pre-Importation Prevention BMPs* & Cultivation Best Management Practices* \\
\hline $\begin{array}{l}\text { Strategic environmental assessment to } \\
\text { plan regional/national biofuel feedstock } \\
\text { strategy. }\end{array}$ & Monitoring / On Site Prevention \\
\hline $\begin{array}{l}\text { Robust quarantine requirements in effect } \\
\text { and enforced }\end{array}$ & $\begin{array}{l}\text { Promote projects with local conversion of } \\
\text { feedstocks. }\end{array}$ \\
\hline $\begin{array}{l}\text { Monitor biofuel industry for compliance } \\
\text { with relevant importation regulations. }\end{array}$ & $\begin{array}{l}\text { Monitor movement of high risk feedstocks } \\
\text { within country. }\end{array}$ \\
\hline $\begin{array}{l}\text { Cost benefit analysis for species } \\
\text { introduction, including potential costs of } \\
\text { invasion, introduction of pests/diseases. }\end{array}$ & $\begin{array}{l}\text { Develop communication and education } \\
\text { programs for transporters and other supply } \\
\text { chain participants to promote monitoring } \\
\text { and awareness }\end{array}$ \\
\hline $\begin{array}{l}\text { Perform WRA, considering ecological } \\
\text { boundaries as well as political }\end{array}$ & $\begin{array}{l}\text { Produce 3rd party audited Environmental } \\
\text { Management Plan to outline use of BMPs. }\end{array}$ \\
\hline $\begin{array}{l}\text { Environmental Impact Assessment } \\
\text { document that includes potential costs of } \\
\text { control, WRA. }\end{array}$ & $\begin{array}{l}\text { Develop and implement monitoring system } \\
\text { to check for escape, pests and pathogens. }\end{array}$ \\
\hline $\begin{array}{l}\text { Support and comply with mandatory and } \\
\text { voluntary quarantine and importation best } \\
\text { practices }\end{array}$ & Utilize buffer zones and wildlife corridors. \\
\hline \multirow{6}{*}{$\begin{array}{l}\text { Possible certification for WRA and } \\
\text { selection of non-invasive species (e.g., } \\
\text { sustainability criteria from Roundtable } \\
\text { for Sustainable Biofuels) }\end{array}$} & $\begin{array}{l}\text { Utilize zero-till planting to reduce } \\
\text { disturbance and open soil. }\end{array}$ \\
\hline & $\begin{array}{l}\text { Plant indicator species that may warn of } \\
\text { pest problems. }\end{array}$ \\
\hline & $\begin{array}{l}\text { Maintain soil health through crop rotation } \\
\text { or mixed cropping. }\end{array}$ \\
\hline & $\begin{array}{l}\text { Use fencing and other barriers to prevent } \\
\text { animal vectoring of seed, propagules, pests, } \\
\text { etc. }\end{array}$ \\
\hline & $\begin{array}{l}\text { Consider use of biological control agents to } \\
\text { reduce spread. }\end{array}$ \\
\hline & Harvest cellulosic biomass prior to \\
\hline
\end{tabular}




\begin{tabular}{|l|l|}
\hline & seed/fruit set. \\
\hline & Use sterile or low-fertility varieties. \\
\hline & Find, identify, and control escapees. \\
& $\begin{array}{l}\text { Convert feedstocks on or near production } \\
\text { site. }\end{array}$ \\
\hline Site nurseries near plantations \\
\hline & $\begin{array}{l}\text { Monitoring plan for vehicles to prevent } \\
\text { spread of seeds/pests, propagules }\end{array}$ \\
\hline & $\begin{array}{l}\text { Monitor transport corridors for escape and } \\
\text { spread of species. }\end{array}$ \\
\hline $\begin{array}{l}\text { Regular monitoring, cleaning of } \\
\text { harvest/transport vehicles }\end{array}$ \\
\hline $\begin{array}{l}\text { Eradication, Containment, Management, } \\
\text { Restoration }\end{array}$ \\
\hline Utilize “polluter pays” strategy \\
\hline & $\begin{array}{l}\text { Surety bonding (financial assurance } \\
\text { requirements) for eradication/clean up }\end{array}$ \\
\hline
\end{tabular}

*Green shading $($ italicized $)=$ government-related practices

Orange shading $=$ feedstock producer-related practices 
Table 3: Noxious weed and weed seed status of selected candidate bioenergy feedstocks

\begin{tabular}{|c|c|c|c|}
\hline $\begin{array}{l}\text { Scientific } \\
\text { name }\end{array}$ & $\begin{array}{l}\text { Common } \\
\text { name }\end{array}$ & Noxious weed listings by state & $\begin{array}{l}\text { Weed seed } \\
\text { listings by } \\
\text { state }\end{array}$ \\
\hline Arundo donax & Giant reed & $\begin{array}{l}\text { California, Nevada, New Mexico, } \\
\text { Texas }\end{array}$ & Nevada \\
\hline $\begin{array}{l}\text { Camelina } \\
\text { sativa }\end{array}$ & $\begin{array}{l}\text { Gold-of- } \\
\text { pleasure }\end{array}$ & None & \\
\hline $\begin{array}{l}\text { Jatropha } \\
\text { curcas }\end{array}$ & $\begin{array}{l}\text { Barbados } \\
\text { nut }\end{array}$ & None & \\
\hline $\begin{array}{l}\text { Miscanthus } \\
\text { sinensis }\end{array}$ & Miscanthus & Connecticut, New Hampshire & \\
\hline $\begin{array}{l}\text { Panicum } \\
\text { virgatum }\end{array}$ & Switchgrass & None & \\
\hline $\begin{array}{l}\text { Paulownia } \\
\text { tomentosa }\end{array}$ & Princess tree & Connecticut, Wisconsin & \\
\hline $\begin{array}{l}\text { Pennisetum } \\
\text { purpureum }\end{array}$ & $\begin{array}{l}\text { elephant } \\
\text { grass }\end{array}$ & None & \\
\hline $\begin{array}{l}\text { Phalaris } \\
\text { arundinacea }\end{array}$ & $\begin{array}{l}\text { Reed } \\
\text { canarygrass }\end{array}$ & $\begin{array}{l}\text { Connecticut, Massachusetts, New } \\
\text { Hampshire, Washington }\end{array}$ & \\
\hline $\begin{array}{l}\text { Pueraria } \\
\text { montana var. } \\
\text { lobata }\end{array}$ & Kudzu & $\begin{array}{l}\text { Connecticut, Florida, Illinois, Kansas, } \\
\text { Kentucky, Massachusetts, } \\
\text { Mississippi, Missouri, New } \\
\text { Hampshire, Ohio, Oregon, } \\
\text { Pennsylvania, Texas, Washington, } \\
\text { West Virginia, Wisconsin }\end{array}$ & $\begin{array}{l}\text { Kansas, } \\
\text { Pennsylvania }\end{array}$ \\
\hline $\begin{array}{l}\text { Salicornia } \\
\text { bigelovii }\end{array}$ & $\begin{array}{l}\text { Dwarf } \\
\text { saltwort }\end{array}$ & $\begin{array}{l}\text { No noxious or invasive listings. } \\
\text { Listed as Threatened/Special concern } \\
\text { in Maine, New Hampshire, New } \\
\text { York }\end{array}$ & \\
\hline Triadica & Chinese & Florida, Louisiana, Mississippi, & \\
\hline
\end{tabular}




\begin{tabular}{|lll|}
\hline sebifera & tallow & Texas \\
\hline & Native & \\
N/A & $\begin{array}{l}\text { Requirie } \\
\text { grasses }\end{array}$ & laws \\
& & \\
\hline
\end{tabular}


Table 4: Invasion history, weed risk assessment scores, and potential legal and policy relevance for a selection of biofuel

feedstock candidates.

\begin{tabular}{|c|c|c|c|c|c|c|c|c|c|c|}
\hline 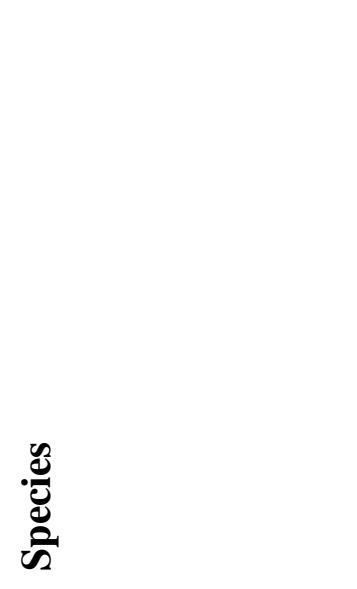 & 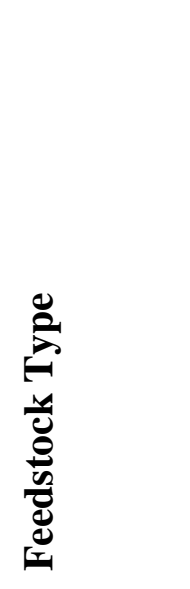 & 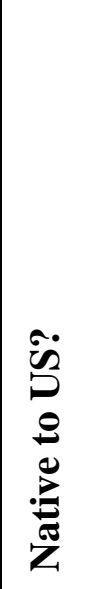 & 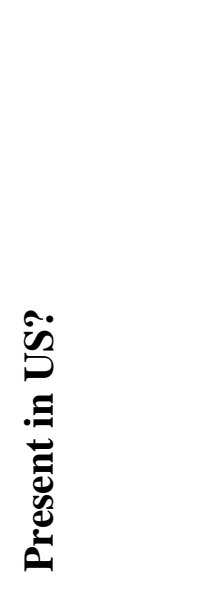 & 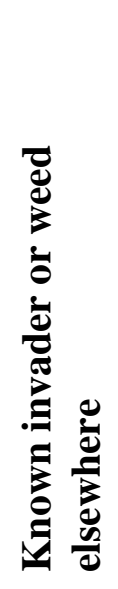 & 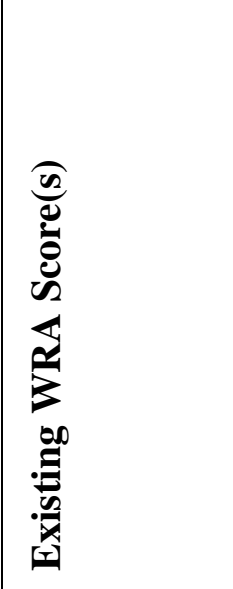 & 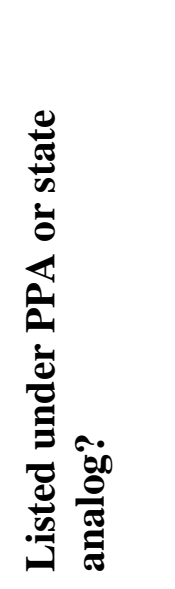 & 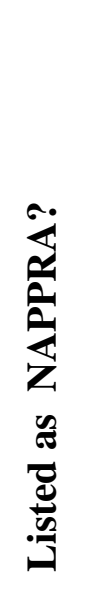 & 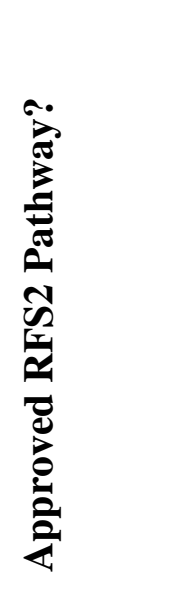 & 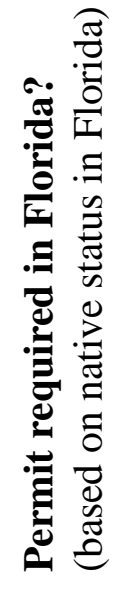 & 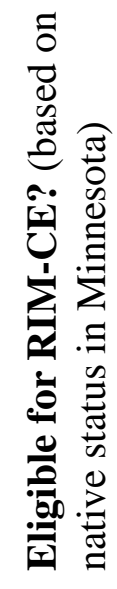 \\
\hline Arundo donax & $\begin{array}{l}\text { Cellulosic } \\
\text { biomass }\end{array}$ & No & Widespread & Yes & Reject & $\begin{array}{l}\text { CA, NV, } \\
\text { NM, TX }\end{array}$ & No & $\begin{array}{l}\text { Yes, with } \\
\text { RMP }\end{array}$ & Yes & No \\
\hline Camelina sativa & Oilseed & No & Widespread & Yes & Reject & No & No & Yes & Yes & No \\
\hline Jatropha curcas & Oilseed & No & $\begin{array}{l}\text { FL, HI, PR, } \\
\text { VI }\end{array}$ & Yes & Reject & No & No & $\begin{array}{l}\text { Under } \\
\text { review }\end{array}$ & Yes & No \\
\hline $\begin{array}{l}\text { Panicum virgatum } \\
\text { (switchgrass) }\end{array}$ & $\begin{array}{l}\text { Cellulosic } \\
\text { biomass }\end{array}$ & Yes & Widespread & Yes & $\begin{array}{l}\text { Conditional } \\
\text { accept / } \\
\text { Reject }\end{array}$ & No & No & Yes & No & Yes \\
\hline Miscanthus sinensis & $\begin{array}{l}\text { Cellulosic } \\
\text { biomass }\end{array}$ & No & Widespread & Yes & Reject & $\mathrm{CT}, \mathrm{NH}$ & No & Yes & Yes & No \\
\hline $\begin{array}{l}\text { Miscanthus } x \\
\text { giganteus (sterile) }\end{array}$ & $\begin{array}{l}\text { Cellulosic } \\
\text { biomass }\end{array}$ & No & Unknown & No & $\begin{array}{l}\text { Accept / } \\
\text { Eval. }\end{array}$ & No & No & Yes & Yes & No \\
\hline
\end{tabular}




\begin{tabular}{|l|l|l|l|l|l|l|l|l|l|}
\hline & & & & & further & & & & \\
\hline Salicornia bigelovii & Oilseed & Yes & Widespread & No & $\begin{array}{l}\text { None } \\
\text { found }\end{array}$ & No & No & No & No \\
\hline
\end{tabular}


Figure 1: Results of Australian Weed Risk Assessment application to various biofuel feedstocks. Blue lines indicate the transition between categories $(\leq 0=$ accept, $1-6=$ evaluate, $>6=$ reject $)$.

Figure 2: Flow chart describing the steps for a feedstock producer to select a low-risk biofuel feedstock, using the examples of Chinese silvergrass (Miscanthus sinensis), jatropha (Jatropha curcas) and switchgrass (Panicum virgatum) based on regulatory listing, native status, and weed risk assessment.

Figure 3: Flow chart describing the steps for a feedstock producer to reduce risk of invasion following introduction and potential eligibility for incentives/subsidies using the examples of Chinese silvergrass (Miscanthus sinensis), jatropha (Jatropha curcas) and switchgrass (Panicum virgatum), based on permitting requirements, best practices and regulations. 


\section{Australian WRA Score}

$-15$

$-10$

$-5$

0

10

15

20

25

30

Agave americana Agave filifera Ailanthus altissima Aleurites moluccana Alnus g/utinosa Arachis glabrata Arundo donax Azadirachta indica Brassica napus Calotropis gigantea Camelina sativa Cannabis sativa Casuarina equisetifolia

Cocos nucifera Copaifera langsdorfil

Crambe abyssinical

Cynara cardunculus -

Elaeis guineensis

Eucalyptus amplifolia : Eucalyptus camaldulensis

Eucalyptus globulus Eucalyptus grandis Eucalyptus robusta

Eucalyptus saligna Eucalyptus urophylla

Euphorbia esula Euphorbia lathyris Fagus sylvatica

Fraxinus uhdei Glycine max

Helianthus annuus Helianthus tuberosus Hibiscus cannabinus Jatropha curcas Kochia scoparia Leucaena leucocephala Linum usitatissimum Macadamia integrifolia Melia azedarach Miscanthus giganteus Miscanthus sinensis Moringa oleiferal Panicum maximum Panicum virgatum Paraserianthes falcataria Paulownia tomentosal Pennisetum purpureum

Persea americana Phalaris arundinacea Pittosporum resiniferum

Pongamia pinnata Prosopis julifiora

Psidium cattleianum

Pueraria lobata

Ricinus communis Robinia pseudoacacial al Saccharum arundinaceum Saccharum officinarum Simmondsia chinensis

Simmondsia chinensis
Sorghum bicolor "sweet" Triadica sebifera Ulex europaeus Zea mays

Barney and DiTomaso, 2008 - Gordon et al. 2008 - Gordon et al. 2011 - HPWRA (www.hpwra.org) - McClay et al. 2010 - Nishida et al. 2008 - Buddenhagen 2009 - Crosti et al. 2010 - Daehler and Carino 2000 - Davis et al. 2010 - Gassó et al. 2009 


\title{
Non-invasive Biofuel Feedstock Selection Process
}

\author{
Example species: Miscanthus sinensis, Jatropha curcas, and Panicum virgatum.
}

\section{Is the feedstock on a federal or state list of noxious weeds or invasive plants?}

USDA and many states maintain lists of species considered noxious and invasive. Listed species are harmful and cannot be legally cultivated without authorization. If not listed, a permit may still be required and other restrictions may apply.

\section{Species not listed.}

Go to step 2.

- M. sinensis: Not listed as noxious or invasive

- J. curcas: Not listed as noxious or invasive.

\section{Species is listed.}

Select an alternate feedstock or work with USDA and state agencies to identify risks and secure permit.

- M. sinensis: Listed in $\mathrm{CT}, \mathrm{NH}$.

\section{Is the feedstock native to the country, state, and region, or already widespread?}

By definition, invasive species are non-native. Select native feedstocks where possible. Introduction of non-native species into the environment may be unlawful in some states. Some incentives are available only for the use of native species.

\section{Feedstock is native.}

Species is not invasive. Go to step 4.

- P. virgatum: Native to the United States. Proceed to cultivation planning.

\section{Feedstock is non-native.}

Permit required for cultivation in Florida. Go to step 3.

- M. sinensis: Non-native, but widespread.

- J. curcas: Non-native; present in FL, HI, PR, VI.

\section{Is the species potentially harmful?}

Species with many invasive traits are at risk of causing environmental and economic harm. Select species with low weed risk assessment scores. Best management practices also require risk assessment prior to introduction.

WRA Score is low. (Accept) Species unlikely to become invasive. Best choice. Go to step 4.
WRA score is marginal.

\section{(Evaluate Further)}

Use WRA expansion tools, expert opinion, and/or cultivation trials prior to widespread use.

- P. virgatum: Conditional Accept where native. Likely to be HIGH RISK where not native (select alternative feedstock if possible).
WRA Score is high. (Reject) Species is a likely invader. Select an alternate feedstock if possible.

Otherwise, employ best practices such as stringent cultivation restrictions and setting aside of funds for control.

- M. sinensis: Likely to be HIGH RISK

- J. curcas: Likely to be HIGH RISK

\section{(4) Proceed to cultivation planning, including use of flow chart titled "Reducing Invasion Risk During Cultivating and Harvesting."}

Work with agencies to determine qualification for incentives, meet other legal requirements, and develop cultivation plan. 


\section{Reducing Invasion Risk During Cultivation and Processing}

Example species: Miscanthus sinensis, Jatropha curcas, and Panicum virgatum.

To be followed after step 4 of "Non-invasive Biofuel Feedstock Selection Process."

\section{Are incentives or subsidies available?}

Federal and state incentives and subsidies benefit feedstock producers or processors. Some programs are limited to non-invasive species, e.g. Biomass Crop Assistance Program (BCAP), Reinvest in Minnesota-Clean Energy (RIM-CE) or approved pathways, e.g. Renewable Fuel Standard (RFS).

\section{Incentives or subsidies available.}

Utilize available benefits for the feedstock and proceed with cultivation.

P. virgatum:

- Native species: eligible for RIM-CE and BCAP.

- Approved RFS pathway.

M.sinensis:

- Approved RFS pathway.

\section{Incentives or subsidies unavailable.}

Proceed with cultivation under plan if economically feasible. If appropriate, work with agencies to qualify feedstock for benefits in the future.

J. curcas:

- RFS pathway approval under review.

- May be ineligible for BCAP due to high invasion risk.

M.sinensis:

- May be ineligible for BCAP due to high invasion risk.

\section{6}

\section{Is a permit required to cultivate or transport the feedstock? What conditions apply?}

Permits are required to import or cultivate federal or state noxious species, species not native to Florida (for cultivation in the state, and new crops produced through genetic engineering (GE)) or other states with similar laws. Permits are conditioned on the use of biosafety protocols such as field monitoring, use of buffer zones, test plots, and posting of financial assurance bonds. Escape can result in seizure and/or destruction of crops and forfeiture of bonds.

\section{No Permit Required.}

Move ahead with production under cultivation plan and best practices.

$P$. virgatum: Native, not noxious or GE crop: no permit required from USDA, FL, or other states.

\section{Permit Required.}

Work with USDA and state agencies to identify risks and secure permit. Comply with all permit conditions.

J. curcas:

- Non-native: permit required in FL.

- Not noxious and not GE: no USDA permit required.

M.sinensis:

- Non-native: permit required in FL.

- Listed as noxious in $\mathrm{CT}$ and $\mathrm{NH}$; permit required.

- Not GE crop: no USDA permit required.

\section{(7) What best practices are needed to reduce the risk of escape?}

Implement required conditions based on cultivation plan. Where no permit is required, follow best practices.

\section{Permit conditions require mitigation.}

Implement required conditions based on cultivation plan. In states where no permit is required, follow voluntary best practices.

J. curcas: Follow permit conditions in FL.

M. sinensis: Follow permit conditions in $\mathrm{FL}, \mathrm{CT}, \mathrm{NH}$.

\section{Voluntary best practices needed.}

Follow IUCN, RSB, or other guidelines to prevent dispersal, monitor escape, and fund potential response capability.

$P$. virgatum: No permit conditions required. Develop cultivation plan.

J. curcas, M.sinensis: Where no permit required, develop cultivation plan.

Examples used here do not constitute legal advice. Check with responsible federal and state agencies to ensure compliance with permitting and other legal requirements. 